\title{
Intelligent Virtual Reality Therapy Systems for Motor and Cognitive Rehabilitation: A Survey based on Clinical Trial Studies
}

\author{
Juliana M. de Oliveira ${ }^{1}$, Roberto Munoz ${ }^{2}$, João B. F. Duarte ${ }^{1}$, Aloísio V. Lira Neto ${ }^{3}$, \\ José Wally M. Menezes ${ }^{3}$, Victor Hugo C. Albuquerque ${ }^{4}$ \\ ${ }^{1}$ University of Fortaleza, Fortaleza/CE, Brazil. \\ ${ }^{2}$ Escuela de Ingenieria, Universidad del Valpariso, Chile. \\ ${ }^{3}$ Instituto Federal de Educação, Ciência e Tecnologia do Ceará,Fortaleza/CE, Brazil. \\ ${ }^{4}$ Universidade Federal do Ceará, Fortaleza/CE, Brazil. \\ Email: victor.albuquerque@ieee.org \\ *Corresponding Author: Victor Hugo C. Albuquerque, Email: victor.albuquerque@ ieee.org
}

How to cite this paper: Oliveira M. de Oliveira, Roberto Munoz, João B. F. Duarte, Aloísio V. Lira Neto, José Wally M. Albuquerque (2021). Intelligent Virtual Reality Therapy Systems for Motor and Cognitive Rehabilitation: A Survey based on Clinical Trial Studies. Journal of Artificial Intelligence and Systems, 3, $130-156$.

https://doi.org/10.33969/AIS.2021.31009

Received: September 10, 2021

Accepted: October 13, 2021

Published: October 15, 2021

Copyright $(2021$ by author(s) and Institute of Electronics and Computer. This work is licensed under the Creative Commons Attribution International License (CC BY 4.0).

http://creativecommons.org/licenses/by/4.0/

\section{Open Access}

\begin{abstract}
Rehabilitation is the process related to the recovery, maintenance or improvement of physical mental and / or cognitive skills necessary to carry out daily activities. Virtual reality therapy, virtual reality (VR) immersion therapy, simulation therapy or virtual reality exposure therapy is an intervention method of using virtual reality technology for psychological or occupational therapy. The possibility of simulating situations necessary for the treatment, controlling variables and reducing the patient's exposure to risks are popular factors for this tool. Many studies indicate that therapy with the aid of virtual reality brings great benefits to the patient. In this article, we present, through a review of 117 articles, the feasibility of applying VR in treatments with clinical trial methodology, identifying through the "Patient, Intervention, Comparison and Outcomes" the characteristics, population, treatment time, forms of comparison and if the results obtained are effective. The characteristics identified during the process show that virtual reality applied to therapies can be used without negative interference in the treatment. In addition, the results show that VR in rehabilitation treatments are motivating and show better results than traditional treatments.
\end{abstract}

Keywords

Intelligent systems, Computer-aided design, Virtual reality therapy, Neurorehabilitation.

\section{Introduction}

Rehabilitation is the process related to the recovery, maintenance or improvement of mental and/or cognitive physical skills required to perform daily activities [1]. Generally, a multidisciplinary team such as physiotherapists, physicians, occupational therapists, psychologists, speech therapists, among others, work together with the patient to achieve this goal. According to WHO [2], around 2.4 billion people currently live with a health problem that benefits from rehabilitation. Several treatment options for rehabilitation that stimulate motor skills and neuropsychological capacity. Physiotherapy sessions, 
occupational therapies, hippotherapy, hydrotherapy, music therapy, exposure therapies and virtual reality therapies [3] are examples used by specialists according to the type of disease, age, patient interest and access to treatment. Virtual reality therapy, virtual reality immersion therapy, simulation therapy or virtual reality exposure therapy, is an intervention method of using virtual reality technology for psychological or occupational therapy. The possibility of simulating situations necessary for the treatment, controlling variables and reducing the patient's exposure to risks are popular factors for this tool. Many studies indicate that therapy with the aid of virtual reality brings great benefits to the patient. This type of therapy is possible because virtual reality is an advanced interface for computer applications, in which users can navigate and interact with a computer-generated three-dimensional environment through multisensory devices such as kinect, leap motion and biomedical equipment [32][33][34].

Virtual reality environments combined with treatments for patients with cerebral palsy [7] [8] [9] [10], stroke [11] [12], phobias [13] [14] [15] [16], Autism (Autism Spectrum Disorder) [17] [18] [19] are examples of works that indicate this reality. To verify the effectiveness of virtual reality (VR) in rehabilitation therapies, several techniques are applied, such as comparisons of results of applications on volunteers. Clinical trial is a prospective biomedical or behavioral research study of humans designed to answer specific questions about biomedical or behavioral interventions (vaccines, drugs, treatments, devices, or new ways of using known drugs, treatments, or devices). Clinical trials are used to determine whether new biomedical or behavioral interventions are safe, effective, and efficient [4][6]and can be used to perform this validation. The aim of this study was to review evidence supporting the effectiveness of virtual reality therapies in trial clinics for motor and cognitive rehabilitation helping us to answer the following questions:

1. What are the characteristics that identify the effectiveness of a clinical trial using VR?

2. What is the period of sessions used for clinical trials using VR?

3. What are the evaluation methods of the trial clinic?

In this research, it is possible to view contributions of works related to the theme over the last 5 years, between 2016 and 2021. In total, 117 works were selected, which were classified according to the acceptance criteria defined in the methodology, based on the information collected and classified through the P.I.C.O. (Patient, Intervention, Comparison and Outcomes), which according to the Evidence-Based Practice (EBP), considers that these elements are fundamental to the research question and the construction of the question for the bibliographic search for evidence. The P.I.C.O. can be used to build research questions of different natures, arising from the clinic, the management of human and material resources, the search for instruments for symptom assessment, among others [20].

\section{Methodology}

Carrying out this research is approached according to the following steps:

1. Develop research terms or keywords related to clinical trial and virtual reality;

2. Search for the most relevant study bases and adapt the keywords and expressions to the search engines referring to each search base;

3. Identify criteria for inclusion and exclusion of articles and classify them by P.I.C.O; and

4. Establish conclusions based on findings related to the topic, as shown in the figure 1.

\subsection{Develop search terms and keywords and objective}

The objective of identifying the keywords and expressions was to obtain a significant number of results related to research on applications related to clinical trial using Virtual Reality as a complementary tool to the motor rehabilitation of patients with neurological disorders, a topic addressed in our study.The query was defined as: "clinical trial" associated 

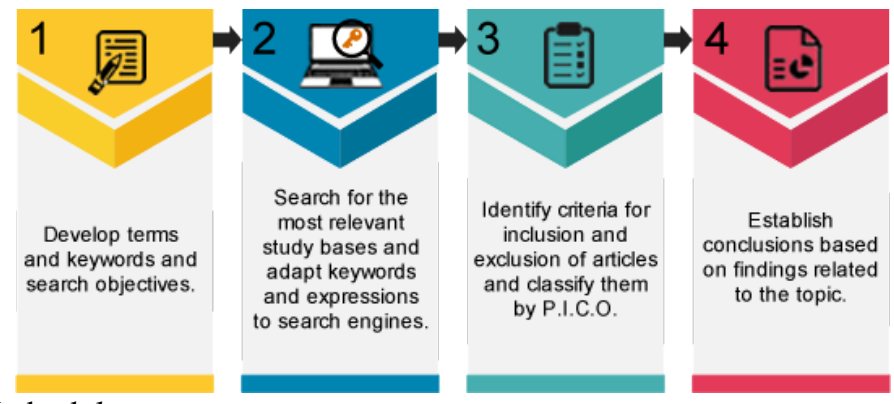

Figure 1. Methodology

with "virtual reality" or "virtual environment" or "artificial environment" in the article title (Publication title), keyword and Abstract applied according to the particularities of the search engines.

\subsection{Search for the most relevant study bases and adapt the keywords and expressions to the search engines referring to each search base.}

The expressions were adapted to search engines according to the rules defined by each query base and filtering according to:

- Period: 2016-2021

- Idiom: English

- Article Types: Magazines in Digital Format

- Query bases: The selection of studies was made on the bases of IEEEXplore, Springer, Science Direct, SAGE, Nature, PLOS One, MDPI, Wiley, BJS Society, Peerj, ACM Digital Library, Inderscience Online, Hindawi, Frontiers.

\subsection{Identify criteria for inclusion and exclusion of articles and classify them by P.I.C.O}

The inclusion and exclusion criteria will be responsible for defining the articles that are relevant to the research topic.

As inclusion criteria are being considered:

- Text and title of works in English

- Works related to the use of VR in clinical or experimental trials treatments

- Articles that, although they do not present the keywords in the research, but which have the name of virtual reality tools such as the name of the VR tool or system that is applied to motor and/or cognitive rehabilitation of patients with neurological disorders or dysfunction.

As exclusion criteria we can indicate:

- Title of the article in English but the text of the article in another language.

- Articles found in more than one search will be considered only one.

- Articles whose content does not portray works on rehabilitation in patients.

- Review or Survey articles, as this is not a study that presents a clinical study.

- Abstract type articles in journals, as there may not be enough information about the applied methodology.

- Articles related to simulations or training of clinical practices (simulation of surgeries and procedures).

- Works that do not fit into the topics related to the area.

- Articles that were not possible to view their full content.

After screening according to the inclusion and exclusion criteria of the works found, the P.I.C.O. is applied. The P.I.C.O. define in its acronym for $\mathrm{P}=$ Patient/Problem/Population, 


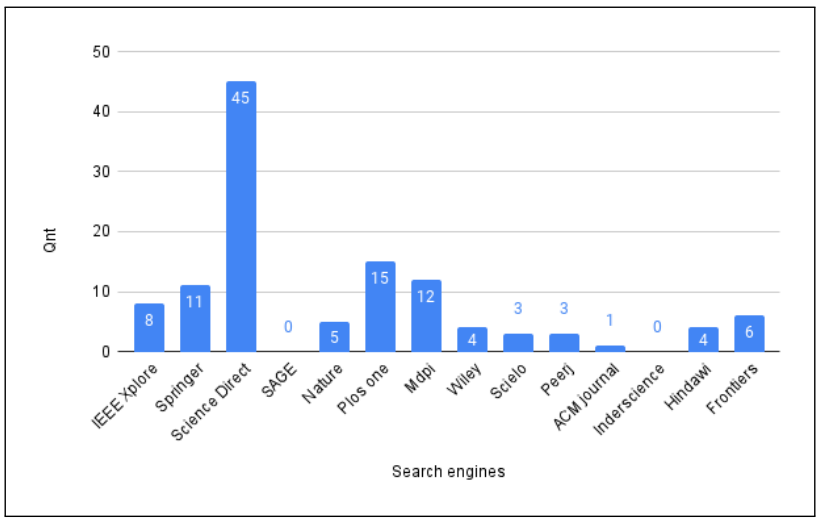

Figure 2. Articles accepted by search engine

that is, who is the target audience in which it is being researched; $\mathrm{I}=$ Intervention (or the experimental variable), which is the type of methodology applied during the applications, usually using a control or placebo group that is compared with the group in which the intervention to be evaluated is applied; $\mathrm{C}=$ Comparison (or the control variable), where the results are compared and the effectiveness of the applied methodology is verified; and $\mathrm{O}=$ Outcome, that is, the result obtained in the study.

The P.I.C.O. is a technique used in evidence-based practice to frame and answer a clinical question in terms of the patient's specific problem that helps clinically relevant evidence in the literature. Defining a clinical question in terms of the patient's specific problem helps the researcher to find clinically relevant evidence in the literature. The P.I.C.O. template is a format to help define the survey question [30] [31].

\subsection{Establish conclusions based on findings related to the topic.}

Findings were divided according to the type of disease or related problem. As the objective of this study is not limited to the disease, but to the type of method applied, to identify the best results obtained, articles are classified and evaluated by groups according to the similarity of the disease. Finally, a general conclusion obtained analyzing the results of each group will be considered.

\subsection{Analysis of Results}

Based on the objectives of this work in the search for an understanding of clinical trial applications using virtual reality in rehabilitation therapies, the following keywords were defined: "Clinical trial" and "Virtual reality", "Clinical Trial" and "Virtual environment", " Clinical essay "and "artificial environment" found in the title, abstract and or keyword. The search in the selected databases and using Boolean operators and keywords, resulted in the data. In total, 527 results were found based on the actions performed in step 2.2 where, 26 from IEEEXplore, 22 from Springer, 69 from ScienceDirect, 0 from SAGE, 21 from Nature, 73 from Plos One, 14 from Mdpi, 5 Wiley, 3 Scielo, 49 from Peerj, 11 from AMC Journal, 0 from Inderscience, 4 from Hindaw and 230 from Frontiers. In total, 117 articles were eligible for analysis in this study, the graph below shows the percentage of articles accepted by journal (Fig. 2).

It can be observed in relation to the distribution of annual publications, that within the range consulted, the year 2020 had the period with the highest number of publications, while the year 2016 was the year that was found the lowest number of publications and over the years there is a growing number of research related to the topic (Fig. 3). 


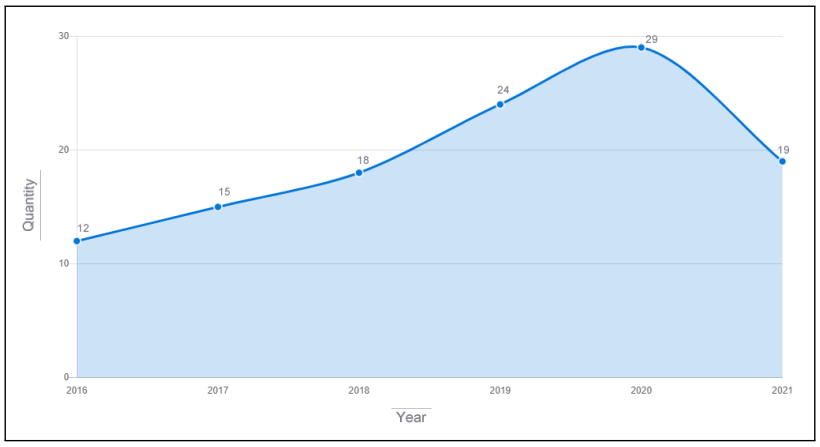

Figure 3. Number of articles per year

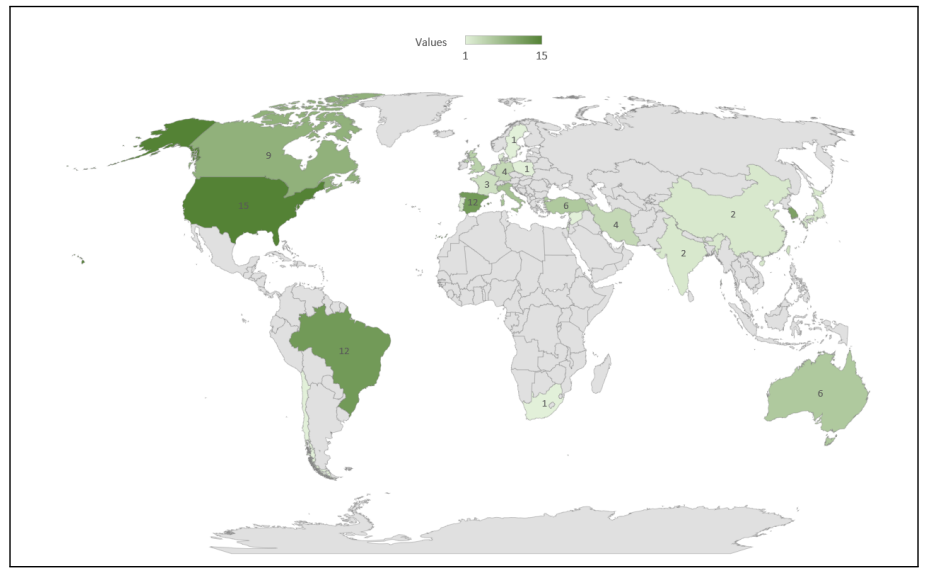

Figure 4. Distributed articles map

During the research, it was observed that the countries that had publications related to the topic between the period 2016 to 2021 are mainly concentrated in the USA, Canada, Brazil and Italy, as shown in the figure 4. According to the surveys, 1.7\% China, 5.1\% Iran, 3.4\% Portugal, 16.9\% USA, 5.1\% France, 6.8\% Spain, 10.2\% Spain, 11.9\% Brazil, 1.7\% The Netherland, 1.7\% Chile, 3.4\% Turkey, 8.5\% South Korea, 13.6\% Canada, 5.1\% Australia. Two works stand out for carrying out interventions in more than one country, such as Ortiz-Catalan et al. [94] and Hsieh, et al. [121].

Below is the list of accepted articles:

Table 1. Classified articles

\begin{tabular}{|c|c|c|c|c|c|c|c|c|}
\hline Author & Illness & $\mathbf{N}$ & Age & Equipment & $\begin{array}{l}\text { Own } \\
\text { Software }\end{array}$ & Groups & $\begin{array}{l}\text { Session } \\
\text { time (min) }\end{array}$ & $\begin{array}{l}\text { Total of } \\
\text { Sessions }\end{array}$ \\
\hline $\begin{array}{l}\text { Al-Nerabieah et } \\
\text { al. [73] }\end{array}$ & $\begin{array}{l}\text { Medical } \\
\text { procedure }\end{array}$ & 64 & $6-10$ & $\begin{array}{l}\text { Device } \\
\text { Mobile }\end{array}$ & $\mathrm{N}$ & 2 & 20 & 1 \\
\hline $\begin{array}{l}\text { Amaral et al. } \\
{[56]}\end{array}$ & $\begin{array}{l}\text { Autism } \\
\text { Spectrum } \\
\text { Disorder }\end{array}$ & 15 & $16-38$ & Computer & $\mathrm{Y}$ & 1 & - & 7 \\
\hline $\begin{array}{l}\text { Amin, Ashfaq } \\
\text { M., et al. [104] }\end{array}$ & $\begin{array}{l}\text { Medical } \\
\text { procedure }\end{array}$ & 30 & $23-68$ & $\begin{array}{l}\text { Device Mobile } \\
\text { Computer }\end{array}$ & $\mathrm{Y}$ & 3 & $20-30$ & 1 \\
\hline $\begin{array}{l}\text { Amiri, Paria, et } \\
\text { al. [103] }\end{array}$ & Pregnancy & 68 & $28-32$ & Computer & $\mathrm{N}$ & 2 & 60 & 4 \\
\hline $\begin{array}{l}\text { Amritha, } \quad \mathrm{N} \\
\text { [117] }\end{array}$ & Balance & 30 & $\mathrm{~m} 25$ & Computer & $\mathrm{Y}$ & 2 & & 4 \\
\hline $\begin{array}{l}\text { Arnoni et al. } \\
\text { [72] }\end{array}$ & $\begin{array}{l}\text { Cerebral } \\
\text { Palsy }\end{array}$ & 35 & $5-14$ & $\begin{array}{l}\text { Game } \\
\text { Console }\end{array}$ & $\mathrm{N}$ & 2 & 45 & 16 \\
\hline Avcil et al. [96] & $\begin{array}{l}\text { Cerebral } \\
\text { Palsy }\end{array}$ & 30 & $4-11$ & $\begin{array}{l}\text { Game Console } \\
\text { Computer }\end{array}$ & $\begin{array}{l}\mathrm{N} \\
\mathrm{Y}\end{array}$ & 2 & 60 & 24 \\
\hline $\begin{array}{l}\text { Barsasellaa et al } \\
\text { [125] }\end{array}$ & Old People & 60 & $60-94$ & Computer & $\mathrm{Y}$ & 2 & 15 & 12 \\
\hline
\end{tabular}




\begin{tabular}{|c|c|c|c|c|c|c|c|c|}
\hline $\begin{array}{l}\text { Bentz et al. } \\
{[141]}\end{array}$. & Phobia & 70 & $18-60$ & $\begin{array}{l}\text { Device } \\
\text { Mobile }\end{array}$ & $\mathrm{Y}$ & 2 & $\begin{array}{l}60 \text { (phase 1) } \\
30 \text { (phase 2) }\end{array}$ & 7 \\
\hline Bortone, I [118] & $\begin{array}{l}\text { Cerebral } \\
\text { Palsy }\end{array}$ & 20 & $\begin{array}{l}7-14 / \\
8-16 / \\
24-32\end{array}$ & Computer & $\mathrm{Y}$ & 3 & - & - \\
\hline Huang et al. [83] & Stroke & 1 & $50-75$ & & $\mathrm{~S}$ & & $30 \mathrm{~min}$ & 54 \\
\hline Botella [148] & Phobia & 63 & $21-70$ & Computer & $\mathrm{Y}$ & 2 & 180 & 1 \\
\hline $\begin{array}{l}\text { Bourque et al. } \\
\text { [97] }\end{array}$ & Amputation & 60 & $>18$ & Computer & $\mathrm{Y}$ & 2 & $15-20$ & 24 \\
\hline $\begin{array}{l}\text { Brown et al. } \\
{[124]}\end{array}$ & Paranoia & 100 & $>18$ & Computer & $\mathrm{Y}$ & 2 & 30 & 1 \\
\hline Buyuk [135] & $\begin{array}{l}\text { Medical } \\
\text { procedure }\end{array}$ & 78 & $5-10$ & $\begin{array}{l}\text { Device } \\
\text { Mobile }\end{array}$ & $\mathrm{Y}$ & 2 & & 1 \\
\hline $\begin{array}{l}\text { C. P. Amaral et } \\
\text { al. [84] }\end{array}$ & $\begin{array}{l}\text { Autism } \\
\text { Spectrum } \\
\text { Disorder }\end{array}$ & 17 & $15-26$ & Computer & $\mathrm{Y}$ & - & 32 & 3 (try) \\
\hline $\begin{array}{l}\text { Calabrò et al. } \\
{[100]}\end{array}$ & Stroke & 24 & $54-73$ & $\begin{array}{l}\text { Proprietary } \\
\text { solution }\end{array}$ & $\mathrm{Y}$ & 2 & 45 & 40 \\
\hline $\begin{array}{l}\text { Cavalcante Neto } \\
\text { et al. [98] }\end{array}$ & Dispraxia & 30 & $7-10$ & $\begin{array}{l}\text { Game } \\
\text { Console }\end{array}$ & $\mathrm{N}$ & 2 & 60 & $12-16$ \\
\hline $\begin{array}{l}\text { Chan, Evelyn, et } \\
\text { al. [102] }\end{array}$ & $\begin{array}{l}\text { Medical } \\
\text { procedure }\end{array}$ & 254 & $4-11$ & $\begin{array}{l}\text { Device } \\
\text { Mobile }\end{array}$ & $\mathrm{Y}$ & 2 & 30 & 1 \\
\hline $\begin{array}{l}\text { Collado Mateo } \\
\text { [169] }\end{array}$ & Fibromyalgia & 76 & $30-75$ & Computer & $\mathrm{Y}$ & 2 & 60 & 16 \\
\hline $\begin{array}{l}\text { De Luca et al. } \\
\text { [58] }\end{array}$ & $\begin{array}{l}\text { Traumatic } \\
\text { brain injury }\end{array}$ & 100 & m 39.9 & $\begin{array}{l}\text { Proprietary } \\
\text { solution }\end{array}$ & $\mathrm{Y}$ & 2 & 60 & 18 \\
\hline $\begin{array}{l}\text { Dehghan, } \\
\text { Fateme, et al. } \\
{[106]}\end{array}$ & $\begin{array}{l}\text { Medical } \\
\text { procedure }\end{array}$ & 40 & $6-12$ & Computer & $\mathrm{Y}$ & 4 & 5 & 1 \\
\hline $\begin{array}{l}\text { dela Barrera } \\
{[156]}\end{array}$ & $\begin{array}{l}\text { Emotional } \\
\text { Problems }\end{array}$ & 119 & $11-15$ & $\begin{array}{l}\text { Device } \\
\text { Mobile }\end{array}$ & $\mathrm{Y}$ & 2 & 50 & - \\
\hline $\begin{array}{l}\text { Dellazizzo et a. } \\
\text { [142] }\end{array}$ & Schizophrenia & 74 & $>18$ & Computer & $\mathrm{Y}$ & 2 & - & 9 \\
\hline $\begin{array}{l}\text { Dellazizzo et al. } \\
\text { [68] }\end{array}$ & Schizophrenia & 10 & $>18$ & Computer & $\mathrm{Y}$ & 2 & & 6 \\
\hline $\begin{array}{l}\text { Deutsch, Judith, } \\
\text { et al. [113] }\end{array}$ & Stroke & 13 & $30-75$ & $\begin{array}{l}\text { Game } \\
\text { Console }\end{array}$ & $\mathrm{N}$ & 2 & 60 & 12 \\
\hline $\begin{array}{l}\text { Dimbwadyo- } \\
\text { Terrer et al. } \\
{[57]}\end{array}$ & Tetraplegia & 21 & $19-65$ & Computer & $\mathrm{Y}$ & 2 & 30 & 15 \\
\hline $\begin{array}{l}\text { du Sert et al. } \\
{[85]}\end{array}$ & Schizophrenia & 19 & $24-62$ & $\begin{array}{l}\text { Device } \\
\text { Mobile }\end{array}$ & $\mathrm{Y}$ & 2 & 45 & 7 \\
\hline $\begin{array}{l}\text { Erdogan et al. } \\
\text { [133] }\end{array}$ & $\begin{array}{l}\text { Medical } \\
\text { procedure }\end{array}$ & 108 & $7-12$ & $\begin{array}{l}\text { Device } \\
\text { Mobile }\end{array}$ & $\mathrm{Y}$ & 4 & $\begin{array}{l}\text { application } \\
\text { duration }\end{array}$ & 1 \\
\hline Fonseca [166] & HAM / TSP & 29 & $18-64$ & $\begin{array}{l}\text { Game } \\
\text { Console }\end{array}$ & $\mathrm{N}$ & 2 & 20 & 20 \\
\hline $\begin{array}{l}\text { France and } \\
\text { Thomas (2018) } \\
\text { [79] }\end{array}$ & Backache & 230 & $18-60$ & Computer & $\mathrm{Y}$ & 2 & - & 18 \\
\hline $\begin{array}{l}\text { Gandolfi et al. } \\
\text { [59] }\end{array}$ & Parkinson & 76 & $>18$ & $\begin{array}{l}\text { Game } \\
\text { Console }\end{array}$ & $\mathrm{N}$ & 2 & 50 & 21 \\
\hline $\begin{array}{l}\text { Garca Vravo et } \\
\text { al. [159] }\end{array}$ & $\begin{array}{l}\text { Cardiovascular } \\
\text { disease }\end{array}$ & 20 & $51.20^{\mathrm{m}}$ & $\begin{array}{l}\text { Game } \\
\text { Console }\end{array}$ & $\mathrm{N}$ & 2 & 60 & 16 \\
\hline $\begin{array}{l}\text { Garrett et al. } \\
\text { [71] }\end{array}$ & Cancer & 12 & $37-73$ & Computer & $\mathrm{N}$ & 2 & 45 & 24 \\
\hline $\begin{array}{l}\text { Gatica-Rojas et } \\
\text { al. [78] }\end{array}$ & $\begin{array}{l}\text { Cerebral } \\
\text { Palsy }\end{array}$ & 32 & $7-14$ & $\begin{array}{l}\text { Game } \\
\text { Console }\end{array}$ & $\mathrm{N}$ & 2 & 35 & 18 \\
\hline $\begin{array}{l}\text { Gerard Fluet } \\
{[115]}\end{array}$ & Stroke & 14 & $3-80$ & Computer & $\mathrm{Y}$ & 3 & 60 & 8 \\
\hline $\begin{array}{l}\text { Ghadimi, S., et } \\
\text { al. [107] }\end{array}$ & $\begin{array}{l}\text { Medical } \\
\text { procedure }\end{array}$ & 28 & $4-5$ & Computer & $\mathrm{N}$ & 2 & - & 2 \\
\hline $\begin{array}{l}\text { Gomes et al. } \\
\text { [93] }\end{array}$ & Mobility & 30 & $71-92$ & $\begin{array}{l}\text { Game } \\
\text { Console }\end{array}$ & $\mathrm{Y}$ & 2 & 50 & 14 \\
\hline $\begin{array}{l}\text { Gülçin et al. } \\
{[126]}\end{array}$ & Cancer & 42 & $6-17$ & $\begin{array}{l}\text { Device } \\
\text { Mobile }\end{array}$ & $\mathrm{Y}$ & 2 & $3-5$ & 1 \\
\hline $\begin{array}{l}\text { Hamzeheinejad, } \\
\text { Negin, et al. } \\
{[114]}\end{array}$ & Stroke & 21 & $19-35$ & Computer & $\mathrm{Y}$ & 2 & 2 & - \\
\hline $\begin{array}{l}\text { Hassett et al. } \\
\text { [69] }\end{array}$ & Mobility & 300 & $\begin{array}{c}18 \quad- \\
101\end{array}$ & $\begin{array}{l}\text { Game } \\
\text { Console }\end{array}$ & $\mathrm{N}$ & 2 & $30-60$ & 60 \\
\hline Hsieh [151] & $\begin{array}{l}\text { Development } \\
\text { delay }\end{array}$ & 147 & $3-12$ & Computer & $\mathrm{Y}$ & 2 & 30 & 8 \\
\hline $\begin{array}{l}\text { Hsieh, et al. } \\
\text { [121] }\end{array}$ & $\begin{array}{l}\text { Multiple } \\
\text { sclerosis }\end{array}$ & 144 & $20-65$ & Computer & $\mathrm{Y}$ & 2 & $15-45$ & 18 \\
\hline
\end{tabular}




\begin{tabular}{|c|c|c|c|c|c|c|c|c|}
\hline $\begin{array}{l}\text { Huang et al. } \\
{[146]}\end{array}$ & $\begin{array}{l}\text { Medical } \\
\text { procedure }\end{array}$ & 50 & $\mathrm{~m} 67.5$ & $\begin{array}{l}\text { Device } \\
\text { Mobile }\end{array}$ & $\mathrm{Y}$ & 2 & $15-45$ & 1 \\
\hline $\begin{array}{l}\text { Ikbali Afsar et al. } \\
\text { [74] }\end{array}$ & Stroke & 35 & $69.42^{m}$ & $\begin{array}{l}\text { Game } \\
\text { Console }\end{array}$ & $\mathrm{N}$ & 2 & 60 & 20 \\
\hline $\begin{array}{l}\text { Doraiswamy et } \\
\text { al.[?] }\end{array}$ & Alzheimer & & & & & & & \\
\hline $\begin{array}{l}\text { Johnson et al. } \\
{[137]}\end{array}$ & Stroke & 60 & $>18$ & $\begin{array}{l}\text { Proprietary } \\
\text { solution }\end{array}$ & $\mathrm{Y}$ & 2 & 45 & 16 \\
\hline Josiah P [120] & $\begin{array}{l}\text { Dyadic } \\
\text { motor } \\
\text { learning }\end{array}$ & 27 & $18-86$ & Computer & $\mathrm{Y}$ & 2 & & 5 \\
\hline Kairy et al. [90] & Stroke & 52 & $>18$ & Computer & $\mathrm{Y}$ & 2 & 30 & 24 \\
\hline Cyr et al. [?] & Anxiety & 54 & & & & & & 2 \\
\hline $\begin{array}{l}\text { Kakoschke et al. } \\
\text { [132] }\end{array}$ & AAT & 24 & $20-45$ & $\begin{array}{l}\text { Device Mobile } \\
\text { Computer }\end{array}$ & $\mathrm{Y}$ & 3 & 10 & \\
\hline Keefe et al. [91] & Schizophrenia & 323 & $\mathrm{~m} 42$ & $\begin{array}{l}\text { Device } \\
\text { Mobile }\end{array}$ & $\mathrm{Y}$ & 2 & $75-90$ & 2 \\
\hline Kim et al [143] & Stroke & 28 & m 53.2 & $\begin{array}{l}\text { Proprietary } \\
\text { solution }\end{array}$ & $\mathrm{Y}$ & 2 & 30 & 20 \\
\hline Kim et al. [140] & Stress & 83 & $19-59$ & $\begin{array}{l}\text { Device } \\
\text { Mobile }\end{array}$ & $\mathrm{Y}$ & 2 & & \\
\hline Koo et al. [70] & $\begin{array}{l}\text { Total Knee } \\
\text { Arthroplasty }\end{array}$ & 60 & m 65 & Computer & Y & 2 & 20 & 10 \\
\hline Kutlu et al. [92] & Stroke & 10 & $>18$ & $\begin{array}{l}\text { Proprietary } \\
\text { solution }\end{array}$ & $\mathrm{Y}$ & 2 & 60 & 17 \\
\hline $\begin{array}{l}\text { Lamargue et al. } \\
\text { [77] }\end{array}$ & $\begin{array}{l}\text { Multiple } \\
\text { Sclerosis }\end{array}$ & 35 & $18-55$ & $\begin{array}{l}\text { Proprietary } \\
\text { solution }\end{array}$ & $\mathrm{Y}$ & 2 & 45 & 50 \\
\hline $\begin{array}{l}\text { Le May et al. } \\
\text { [164] }\end{array}$ & $\begin{array}{l}\text { Medical } \\
\text { procedure }\end{array}$ & 188 & $7-17$ & $\begin{array}{l}\text { Game } \\
\text { Console }\end{array}$ & $\mathrm{Y}$ & 2 & 20 & 1 \\
\hline Lee $[158]$ & Old People & 56 & $80.23^{m}$ & $\begin{array}{l}\text { Device } \\
\text { Mobile }\end{array}$ & $\mathrm{Y}$ & 2 & 50 & 20 \\
\hline Lee [67] & Stroke & 42 & $>18$ & $\begin{array}{l}\text { Device } \\
\text { Mobile }\end{array}$ & $\mathrm{N}$ & 2 & 120 & 30 \\
\hline Lee et al. [63] & Stroke & 18 & $>18$ & Computer & $\mathrm{Y}$ & 2 & 30 & 18 \\
\hline $\begin{array}{l}\text { Liang Peng et Al. } \\
\text { [116] }\end{array}$ & Stroke & 24 & $18-70$ & Computer & $\mathrm{Y}$ & 2 & 45 & 10 \\
\hline Liao et al [172] & Old People & 42 & $>65$ & Computer & $\mathrm{Y}$ & 2 & 60 & 36 \\
\hline $\begin{array}{l}\text { Lima Reblo et al. } \\
\text { [139] }\end{array}$ & Old People & 37 & $>18$ & Computer & Y & 2 & - & 16 \\
\hline $\begin{array}{l}\text { Liu, Wang, et al. } \\
\text { [109] }\end{array}$ & Addiction & 95 & $18-45$ & Computer & $\mathrm{Y}$ & 4 & 40 & 2 \\
\hline $\begin{array}{l}\text { Machulska et al. } \\
\text { [134] }\end{array}$ & Addiction & 96 & $\mathrm{~m} 50,3$ & Computer & $\mathrm{Y}$ & 2 & 90 & \\
\hline Maier, M [119] & Stroke & 11 & $45-75$ & Computer & $\mathrm{Y}$ & 2 & 30 & 30 \\
\hline $\begin{array}{l}\text { Manuli et al. } \\
\text { [88] }\end{array}$ & Stroke & 90 & $\mathrm{~m} 43$ & $\begin{array}{l}\text { Proprietary } \\
\text { solution }\end{array}$ & $\mathrm{Y}$ & 3 & & 40 \\
\hline $\begin{array}{l}\text { Maroo Souto et } \\
\text { al. [171] }\end{array}$ & Schizophrenia & 61 & $18-50$ & Computer & $\mathrm{Y}$ & 2 & 60 & 12 \\
\hline $\begin{array}{l}\text { Marques Sule et } \\
\text { al. [138] }\end{array}$ & Stroke & 29 & $>18$ & $\begin{array}{l}\text { Game } \\
\text { Console }\end{array}$ & $\mathrm{N}$ & 2 & & 8 \\
\hline Marshall [154] & Aphasia & 34 & m 53.5 & Computer & $\mathrm{Y}$ & 4 & 20 & 30 \\
\hline Marshall [150] & Aphasia & 20 & m 57.8 & Computer & $\mathrm{Y}$ & 2 & - & 25 \\
\hline $\begin{array}{l}\text { Melcer et a. } \\
{[131]}\end{array}$ & $\begin{array}{l}\text { Medical } \\
\text { procedure }\end{array}$ & 60 & $>18$ & $\begin{array}{l}\text { Game } \\
\text { Console }\end{array}$ & $\mathrm{Y}$ & 2 & $5-15$ & 1 \\
\hline $\begin{array}{l}\text { Meyns et al. } \\
{[76]}\end{array}$ & $\begin{array}{l}\text { Cerebral } \\
\text { Palsy }\end{array}$ & 41 & $7-14$ & $\begin{array}{l}\text { Game } \\
\text { Console }\end{array}$ & $\mathrm{N}$ & 2 & 30 & 30 \\
\hline $\begin{array}{l}\text { Molhemi et al. } \\
\text { [128] }\end{array}$ & $\begin{array}{l}\text { Multiple } \\
\text { Sclerosis }\end{array}$ & 39 & $18-64$ & $\begin{array}{l}\text { Game } \\
\text { Console }\end{array}$ & $\mathrm{N}$ & 2 & 35 & 18 \\
\hline $\begin{array}{l}\text { Montero-Alía et } \\
\text { al. [101] }\end{array}$ & Mobility & 380 & $>60$ & $\begin{array}{l}\text { Game } \\
\text { Console }\end{array}$ & $\mathrm{Y}$ & 2 & 30 & 24 \\
\hline $\begin{array}{l}\text { Garcia-Zapirain, } \\
\text { B. }[163]\end{array}$ & Old People & 40 & $83.11^{\mathrm{m}}$ & Computer & $\mathrm{Y}$ & 2 & 20 & 9 \\
\hline $\begin{array}{l}\text { Mugueta } \\
\text { Aguinaga et } \\
\text { al. [161] }\end{array}$ & Old People & 46 & $>65$ & Computer & $\mathrm{Y}$ & 2 & 20 & 18 \\
\hline Nasseri [168] & $\begin{array}{l}\text { Multiple } \\
\text { Sclerosis }\end{array}$ & 38 & $18-60$ & $\begin{array}{l}\text { Device } \\
\text { Mobile }\end{array}$ & $\mathrm{Y}$ & 2 & - & 7 \\
\hline $\begin{array}{l}\text { Norouzi- } \\
\text { Gheidari } \\
\text { al. [66] }\end{array}$ & Stroke & 23 & $\begin{array}{l}\mathrm{m} 42.2 \\
-57.6\end{array}$ & Computer & $\mathrm{Y}$ & 2 & 44 & 8 \\
\hline Norr et al. [87] & $\begin{array}{l}\text { Suicidal } \\
\text { ideation }\end{array}$ & 162 & $>18$ & Computer & $\mathrm{Y}$ & 2 & $90-120$ & 10 \\
\hline Norr, et al. [89] & Stress & 162 & $>18$ & Computer & $\mathrm{Y}$ & 2 & $90-120$ & \\
\hline Odin et al. [81] & Mobility & 20 & $49-65$ & Computer & $\mathrm{Y}$ & 2 & 45 & 1 \\
\hline
\end{tabular}




\begin{tabular}{|c|c|c|c|c|c|c|c|c|}
\hline $\begin{array}{l}\text { Oliveira et al. } \\
{[170]}\end{array}$ & Alzheimer & 14 & $>60$ & Computer & $\mathrm{Y}$ & 2 & $30-45$ & 16 \\
\hline $\begin{array}{l}\text { Ortiz-Catalan et } \\
\text { al. [94] }\end{array}$ & Amputation & 14 & $26-74$ & Computer & $\mathrm{Y}$ & 1 & $2 \mathrm{~h}$ & 12 \\
\hline $\begin{array}{l}\text { Park, Jin-Woo, } \\
\text { et al. [112] }\end{array}$ & $\begin{array}{l}\text { Medical } \\
\text { procedure }\end{array}$ & 80 & $4-10$ & $\begin{array}{l}\text { Device } \\
\text { Mobile }\end{array}$ & $\mathrm{Y}$ & 2 & 4 & 1 \\
\hline $\begin{array}{l}\text { Patrício et al. } \\
\text { [95] }\end{array}$ & HAM / TSP & 26 & m 49 & $\begin{array}{l}\text { Game } \\
\text { Console }\end{array}$ & $\mathrm{Y}$ & 2 & 20 & 20 \\
\hline $\begin{array}{l}\text { Pazzaglia et al. } \\
\text { [82] }\end{array}$ & Parkinson & 51 & $\mathrm{~m} 71$ & $\begin{array}{l}\text { Proprietary } \\
\text { solution }\end{array}$ & $\mathrm{Y}$ & 2 & 40 & 18 \\
\hline $\begin{array}{l}\text { Pedreira } \\
\text { Fonseca da } \\
{[75]}\end{array}$ & Stroke & 27 & $18-65$ & $\begin{array}{l}\text { Game } \\
\text { Console }\end{array}$ & $\mathrm{N}$ & 2 & 60 & 20 \\
\hline $\begin{array}{l}\text { Pericot- } \\
\text { Valverde, Irene, } \\
\text { et al. [111] }\end{array}$ & Addiction & 102 & $>18$ & Computer & $\mathrm{Y}$ & 2 & 90 & 5 \\
\hline $\begin{array}{l}\text { Perin, } \\
\text { Alessandro, } \\
\text { et al. [105] }\end{array}$ & $\begin{array}{l}\text { Medical } \\
\text { procedure }\end{array}$ & 40 & $18-70$ & Computer & $\mathrm{Y}$ & 3 & 30 & 1 \\
\hline Perry et al. [55] & Amputation & 14 & $20-30$ & $\begin{array}{l}\text { Proprietary } \\
\text { solution }\end{array}$ & $\mathrm{Y}$ & 2 & $20-30$ & 20 \\
\hline $\begin{array}{l}\text { Peultier-Celli et } \\
\text { al. [99] }\end{array}$ & $\begin{array}{l}\text { symptomatic } \\
\text { knee } \\
\text { osteoarthritis }\end{array}$ & 236 & m 64 & $\begin{array}{l}\text { Device } \\
\text { Mobile }\end{array}$ & $\mathrm{Y}$ & 2 & 25 & 18 \\
\hline $\begin{array}{l}\text { Quero et al. } \\
{[160]}\end{array}$ & $\mathrm{AjD}$ & 57 & $18-54$ & Computer & $\mathrm{Y}$ & 2 & 90 & $6-8$ \\
\hline Radder [155] & Old People & 91 & $\mathrm{~m} 73$ & Computer & $\mathrm{Y}$ & 3 & $\begin{array}{l}180 / \text { per } \\
\text { week }\end{array}$ & 21 \\
\hline $\begin{array}{l}\text { Ramnath et al. } \\
\text { [153] }\end{array}$ & Old People & 45 & $\mathrm{~m} 72$ & $\begin{array}{l}\text { Game } \\
\text { Console }\end{array}$ & $\mathrm{N}$ & 2 & 60 & 24 \\
\hline $\begin{array}{l}\text { Ramos et al. } \\
{[149]}\end{array}$ & Prism shift & 20 & m 27.1 & Computer & $\mathrm{Y}$ & 3 & - & 1 \\
\hline $\begin{array}{l}\text { Ribeiro et al. } \\
\text { [62] }\end{array}$ & Pregnancy & 32 & $18-35$ & $\begin{array}{l}\text { Game } \\
\text { Console }\end{array}$ & $\mathrm{N}$ & 2 & 30 & 12 \\
\hline Ryu et al. [157] & $\begin{array}{l}\text { Medical } \\
\text { procedure }\end{array}$ & 120 & $4-8$ & $\begin{array}{l}\text { Device } \\
\text { Mobile }\end{array}$ & $\mathrm{Y}$ & 2 & 3 & 1 \\
\hline $\begin{array}{l}\text { Ryu, J. H., et al. } \\
\text { [108] }\end{array}$ & $\begin{array}{l}\text { Medical } \\
\text { procedure }\end{array}$ & 69 & $4-10$ & $\begin{array}{l}\text { Device } \\
\text { Mobile }\end{array}$ & $\mathrm{Y}$ & 2 & 4 & 1 \\
\hline $\begin{array}{l}\text { Ryu, Jung-Hee, } \\
\text { et al. [110] }\end{array}$ & $\begin{array}{l}\text { Medical } \\
\text { procedure }\end{array}$ & 70 & $4-10$ & Computer & $\mathrm{Y}$ & 2 & 5 & 1 \\
\hline $\begin{array}{l}\text { Schuster Amf et } \\
\text { al. [145] }\end{array}$ & Stroke & 54 & $20-81$ & Computer & $\mathrm{Y}$ & 2 & 45 & 16 \\
\hline $\begin{array}{l}\text { Sheehy et al. } \\
{[80]}\end{array}$ & Stroke & 76 & $>50$ & Computer & $\mathrm{Y}$ & 2 & $30-45$ & $10-12$ \\
\hline Shimizu [165] & Schizophrenia & 8 & $18-64$ & $\begin{array}{l}\text { Game } \\
\text { Console }\end{array}$ & $\mathrm{N}$ & 2 & 35 & 24 \\
\hline Sieluycki [152] & Athletes & 24 & $12-28$ & Computer & $\mathrm{Y}$ & 2 & 20 & 5 \\
\hline Silva et al. [61] & $\begin{array}{l}\text { Cardiovascular } \\
\text { disease }\end{array}$ & 27 & $>45$ & $\begin{array}{l}\text { Game } \\
\text { Console }\end{array}$ & $\mathrm{N}$ & 2 & 60 & 16 \\
\hline $\begin{array}{l}\text { Soon Young Lee } \\
\text { and Jiyeon Kang } \\
{[123]}\end{array}$ & Sleep quality & 48 & $>18$ & $\begin{array}{l}\text { Device } \\
\text { Mobile }\end{array}$ & $\mathrm{Y}$ & 2 & 30 & 1 \\
\hline $\begin{array}{l}\text { Spiegel et al. } \\
\text { [147] }\end{array}$ & $\begin{array}{l}\text { Medical } \\
\text { procedure }\end{array}$ & 120 & $>18$ & $\begin{array}{l}\text { Device } \\
\text { Mobile }\end{array}$ & $\mathrm{Y}$ & 2 & 10 & 1 \\
\hline $\begin{array}{l}\text { Sulfikar Alli et } \\
\text { al. [136] }\end{array}$ & Stroke & 120 & $>18$ & $\begin{array}{l}\text { Proprietary } \\
\text { solution }\end{array}$ & $\mathrm{Y}$ & 2 & 30 & 30 \\
\hline Tejera et al. [65] & $\begin{array}{l}\text { Chronic non- } \\
\text { specific pain } \\
\text { in the neck }\end{array}$ & 44 & $18-65$ & $\begin{array}{l}\text { Device } \\
\text { Mobile }\end{array}$ & $\mathrm{N}$ & 2 & - & 8 \\
\hline $\begin{array}{l}\text { Tennant et al. } \\
{[130]}\end{array}$ & Cancer & 90 & $7-19$ & $\begin{array}{l}\text { Device } \\
\text { Mobile }\end{array}$ & $\mathrm{Y}$ & 2 & 10 & \\
\hline Thielbar [129] & Stroke & 20 & - & Computer & $\mathrm{Y}$ & 2 & - & 8 \\
\hline $\begin{array}{l}\text { Thomas et al. } \\
\text { [86] }\end{array}$ & Backache & 52 & $18-50$ & Computer & $\mathrm{Y}$ & 2 & 15 & $8-12$ \\
\hline Tuba et al. [122] & $\begin{array}{l}\text { Medical } \\
\text { procedure }\end{array}$ & 139 & $4-10$ & $\begin{array}{l}\text { Device } \\
\text { Mobile }\end{array}$ & $\mathrm{N}$ & 3 & 15 & 1 \\
\hline Volpi [167] & Hypertensive & 49 & $50-69$ & $\begin{array}{l}\text { Device } \\
\text { Mobile }\end{array}$ & $\mathrm{Y}$ & 2 & - & 84 \\
\hline $\begin{array}{l}\text { Waliño- } \\
\text { Paniagua } \\
\text { al. [60] }\end{array}$ & $\begin{array}{l}\text { Multiple } \\
\text { sclerosis }\end{array}$ & 26 & $32-62$ & Computer & $\mathrm{Y}$ & 2 & 30 & 20 \\
\hline Wall [162] & MCI & 14 & $\mathrm{~m} 82.8$ & $\begin{array}{l}\text { Device } \\
\text { Mobile }\end{array}$ & $\mathrm{Y}$ & 2 & $30-45$ & $8-10$ \\
\hline
\end{tabular}




\begin{tabular}{|c|c|c|c|c|c|c|c|c|}
\hline Yang et al. [64] & $\begin{array}{l}\text { Autism } \\
\text { Spectrum } \\
\text { Disorder }\end{array}$ & 17 & $\mathrm{~m} 22$ & Computer & $\mathrm{Y}$ & 2 & $10 \mathrm{~h}$ & - \\
\hline Yeo et al.[127] & $\begin{array}{l}\text { Mood- } \\
\text { related } \\
\text { benefits }\end{array}$ & 96 & $18-75$ & Computer & $\mathrm{Y}$ & 2 & 5 & 1 \\
\hline $\begin{array}{l}\text { Zeigelboim } \\
{[144]}\end{array}$ & $\begin{array}{l}\text { Hereditary } \\
\text { spastic } \\
\text { paraplegia }\end{array}$ & 40 & $>18$ & $\begin{array}{l}\text { Game } \\
\text { Console }\end{array}$ & $\mathrm{N}$ & 2 & 30 & 20 \\
\hline
\end{tabular}

Legend: TSP/HAM - Tropical spastic paraparesis/HTLV-1 associated myelopathy; AjD - Adaptation Disorder ; MCI - Mild cognitive impairment; AAT - Approach Prevention Training;

\subsection{Population}

The population observed during this study indicates that clinical trials procedures using VR are being widely used in different types of treatment approaches involving Motor Functions, Cognitive Functions, Anxiety, social inclusion, addictions and quality of life analysis. Most of the articles researched were applied to Patients with Stroke, Works with Elderly People, mainly in the care of frailty caused by age (risk of falling, loss of balance and muscle strength), Schizophrenia, Cerebral Palsy, Multiple Sclerosis, Application of medical procedures 5 .

The number of people qualified for the interventions was related to the type of methodology applied in the related works. The mean of patients who participated in the interventions was Mean - 63.67 and its Median - 41.5. The age group included a minimum age of 4 years and a maximum of 101 years. All studies elected exclusion criteria and patient classification for intervention. The items considered in the exclusion criteria were patients outside the age group defined in the intervention methodology, not meeting any metrics identified as a result of an examination or previous assessment, sensitivity to light, in addition to having the free will participation of the patient to participate in the intervention. The initial number of patients for the interventions was not considered, only the patients who participated in the entire research proposal.

\subsection{Intervention}

The articles found during this research, the rehabilitation process is related to the motivation to provide the patient with a life close to normality, either by the psychological aspect in reducing anxiety, phobias, or in the motor recovery process and in the recognition of the body through the movements necessary to regain independence from daily activities. Complementary therapy through virtual reality is presented to all researched works as an

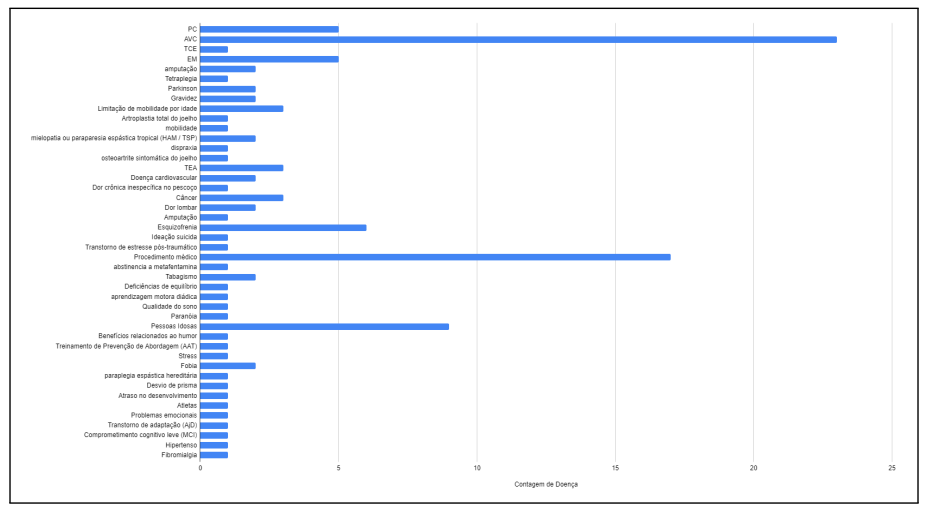

Figure 5. Number of items per illness 


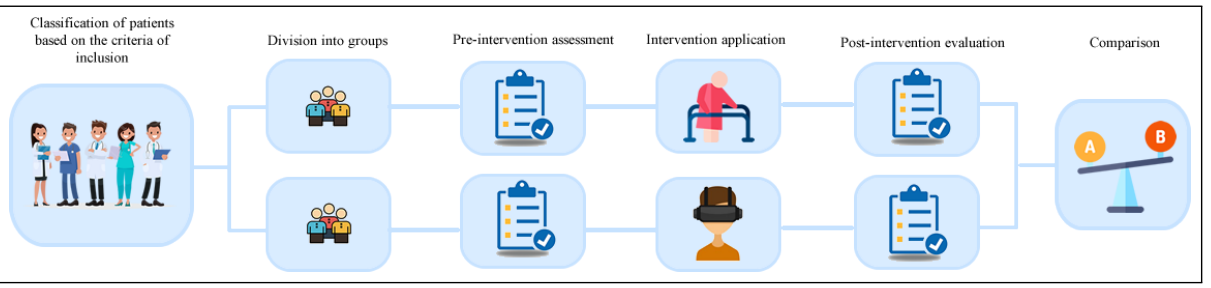

Figure 6. Clinica trial process

Table 2. Classification and domain according to ICF

\begin{tabular}{lllll}
\hline & \multicolumn{2}{l}{ Part 1: Functionality and Disability } & \multicolumn{2}{l}{ Part 2: Contextual Factors } \\
\hline $\begin{array}{l}\text { Components } \\
\begin{array}{l}\text { Environmental } \\
\text { Factors }\end{array}\end{array}$ & $\begin{array}{l}\text { Body Functions } \\
\text { Personal Factors }\end{array}$ & Structures & Activities & Participation \\
\hline Body Domain & $\begin{array}{l}\text { Functions Body } \\
\text { Structures }\end{array}$ & $\begin{array}{l}\text { Vital Areas (tasks, } \\
\text { actions) }\end{array}$ & $\begin{array}{l}\text { External influences } \\
\text { on functionality and } \\
\text { disability }\end{array}$ & $\begin{array}{l}\text { Internal influences } \\
\text { on functionality and } \\
\text { disability }\end{array}$ \\
\hline
\end{tabular}

alternative to a rehabilitation process, with the objective of seeking a speedier treatment or providing a new motivation for the patient to continue in their recovery process.

The process of a clinical trial application consists of a previous classification of patients who will participate, through criteria that indicate the necessary profile and exclusion criteria. These criteria can be indicated as age group, clinical conditions, attendance of treatment, among other aspects. After classification, patients are divided into distinct groups, usually a control group, in which traditional methods are applied and the intervention group applying a new methodology or protocol. Patients are divided blindly, through randomization or random selection systems. After dividing the patients into groups, a prior assessment is applied to compare future results, the assessments are the same for both groups. The intervention is carried out using the methodology indicated by the professionals, the application time, the tools and the duration of the sessions are indicated according to the objective of the treatment. After performing the intervention, an assessment by intervention is performed to compare the pre- and post-assessment, with this the Comparison is performed for each patient and finalizing the analysis and comparison between the groups indicated in the Clinical Trial, as shown in the figure 6.

The articles were classified according to the ICF (International Classification of Functioning, Disability and Health). The ICF is a classification developed by the WHO (World Health Organization) and aims to provide a unified and standardized language and a framework for describing health and health-related status. Your specific goals can be summarized as follows:

- Provide a scientific basis for understanding and studying health determinants, outcomes and health-related conditions;

- Establish a common language for the description of health and health-related conditions, to improve communication between different users, such as health professionals, researchers, policy makers and decision-makers and the public, including people with disabilities;

- Allow comparison of data across countries, across disciplines related to health care, across services, and at different points in time;

- Provide a coding scheme for health information systems.

The ICF was selected for grouping the articles, due to the consideration that one of its applications is intended to be used as a clinical tool assessing needs, matching treatments with specific conditions, evaluating professional skills, rehabilitation and the results [54] (Table 3);

Based on this related classification, we consider the classification of the articles studied as reacting to Part 1: Functionality and Disability, onde 92 foram classificados de como 
Tratamentos de Funções e Estruturas do Corpo e 26 como Atividades e Participação.

\subsubsection{Group profile}

Most of the Clinical Trial groups listed used the methodology generally involving two groups, corresponding to $95.72 \%$ of the articles presented, a Control Group (CG) in which they apply traditional treatment procedures and the Intervention Group using Virtual Reality (GRV) with application of Virtual Reality during the treatment sessions. Some studies showed more than two groups such as Marshall [154] that used 6 groups $(0.85 \%)$, Radder et al. [155], Ramos et al. [149], Kakoschke et al. [132], Tuba et al. [122], Bortone, I [118], Gerard Fluet [115], Perin, Alessandro, et al. [105], Amin, Ashfaq M., et al. [104], Manuli et al. [88], Gerard Fluet [115] conducted their research with 3 groups (7.69\%), Erdogan et al. [133], Liu, Wang, et al. [109], Dehghan, Fateme, et al. [106] worked with 4 groups (2.56\%) and 2 articles such as Ortiz-Catalan et al. [94], Amaral et al. [56] that used only 1 group (1.70\%). Regarding the work by Kim et al. [140] 2 intervention groups divided by age group. The number of groups per study was Average - 2.14 and Median - 2. All groups consider the same method of comparison. There was a concern to divide patients into groups equally and in a blind selection, that is, the patient was randomly assigned to a certain group.

\subsubsection{Duration}

The duration was presented according to the purpose of the interventions. For anxietyreducing interventions for medical procedures, such as surgical interventions and invasive procedures such as venipuncture, only one day of application was necessary [102] [104] [105] [106] [108] [110] [112].

- The time of each session varies between 4 to 120 minutes, with an approximate average of 39.02 minutes and a Median of 30 minutes. Some treatments did not report a specific period of sessions as it varied according to the execution of a task or during the application of a procedure.

- The range of sessions 1 to 7 times a week.

- The total amount of sessions ranged from 1 to 60 sessions, with total treatment treatment duration ranging from 1 day to 18 weeks ( 3 months approximately). Approximate average of 14.19 sessions and Median of 14 sessions.

These items are not considering the evaluation times before and after the intervention period, only the period related to the application of the clinical trial.

\subsubsection{Technology of intervention groups in VR}

The technologies involved during the application of VR in the rehabilitation process were completed according to the objective of the intervention and the capacity to confirm the aptitude for its use. Exclusion criteria were considered as factors for patient selection, such as light hypersensitivity, movement limitation, age group or risks that could affect the patient's health. In the studies, software intended for entertainment and adapted for rehabilitation treatments were used, representing $22.04 \%$ of the studies studied, and $77.96 \%$ used software developed specifically for the context of rehabilitation.

Regarding the hardware selected for interventions, $22.89 \%$ of the works used Mobile Devices such as Tablets and Smartphones, $48.30 \%$ used the Computer, around $20.34 \%$ Games consoles on the market for entertainment purposes such as Wii and Xbox and 8.47\% of these studies used proprietary solutions with their own hardware development. Some interventions like Tennant et al. [130], Ryu et al. [157], Kakoschke et al. [132], Amin, Ashfaq M., et al. [104], Avcil et al. [96], Hassett et al. [69] used more than one hardware 
device to compare which approach among the groups of their clinical trials showed better results during their research.

Virtual reality can be considered as the combination of three basic ideas: immersion, interaction and involvement [35], [36].

According to the type of immersion, VR can be immersive, that is, eliminating noise from real environments from devices that transport the user to a completely virtual environment. Normally, an immersive system is achieved using VR glasses, but there are also immersive systems based in rooms with projections of visions on the walls, ceiling, and floor, where this visual sensation of immersion is directly linked to the three-dimensional presentation of objects, with the sensation of depth, achieved from the stereoscopic visualization [? ]. And the non-immersive virtual reality, unlike the immersive one, presents experiences through devices that do not provide this immersion but through the feeling of non-inclusion, that is, when the user is, in theory, partially transported to the virtual world, through a window, but it continues to feel predominantly in the real world, but considers three-dimensional projections of this virtual environment in the real world, through image projection devices such as: TV, monitors or projectors and use of output peripherals such as keyboards, joysticks, mouse, for example. Its advantage is to avoid technical limitations and problems arising from the use of glasses and other peripherals, ease of use and cost reduction. Based on this understanding, the use of immersive and non-immersive virtual reality present $49 \%$ and $51 \%$ of the works respectively.

Iteration with a developed artificial environment is related to the communication between human action and the result of that action processed by the computer, resulting through a response in the virtual environment and the user's involvement when interacting with the virtual system for certain actions. The interaction can be passive, like watching television, in this type of iteration there is no interference from user actions within the virtual environment, or active, when the user has the ability to manipulate objects in a virtual environment.

Engagement, on the other hand, is related to the degree of motivation to engage a user in a given activity. The involvement can be passive, like watching television, or active, like participating in a game with an opponent $14.53 \%$ of the works have passive involvement and $85.47 \%$ active involvement, this data presents a direct relationship of the iteration on involvement in virtual environments.

\subsection{Comparasion}

The comparison had a very significant variation in relation to the articles. Each article presented a different method for comparing the results, making it impossible to compare them according to the type of disease. These assessment methods are identified by practitioners to assess through one or more systems for different purposes and, are already used for patient measurements in traditional treatments.

The methods of comparison were related to 3:

None of the articles considered information commonly saved in entertainment games such as time, number of errors and successes to assess the patient's evolution.

\subsection{Outcomes}

Of the results obtained, most articles had good results related to intervention using VR. $15.38 \%$ of the articles revealed that there was no significant difference in outcome between groups, $84.62 \%$ indicate that in one or more metrics there were significant improvements in groups that used VR in their intervention. However, it is not clear that the results obtained through the metrics used in comparing the groups remain after the intervention period, demonstrating the need for maturation, increased number of participants and postintervention evaluation time during patient follow-up. Favorable items presented subjectively during this research, is that the application of VR in rehabilitation treatments increases 
Table 3. Evaluations according goals

\begin{tabular}{ll}
\hline Classification & Measure \\
\hline Motor function & ICC; FMA; GMFCS; MMT; WMFT; MAS; MACS; 6MWT; RMT; OLS; FRT; TUG; \\
& BBT; FMA-UE; FIM; FMS; FMUE; VADL; VRFCAT; 10MWT; \\
Anxiety & mYPAS-SF; AES/DES; CAPS; STAI; SCAS; m-YPAS; STAI Y-1; ADIS-IV-L; STAI Y-2; \\
& CAM-S; DASS-21; \\
Fear & CFS; W-DEQ; FPS-R; PedIMMPACT; CAPS; FES-I; \\
Balance & ABC scale; BBS; CTSIB; \\
Stress & CSSQ; \\
Behavior & BAT; W-B faces; ATHQ; VABS; FBRS; OSBD; PBRS; ARI; \\
Physiological & H.P; METS; SpO2; PPA; EEG; \\
conditions & \\
Paranoia & GPTS-B; AIHQ \\
Mental disorders & DSM-IV-TR \\
Pains & PedIMMPACT; SUDs; PI; CPM; PCS; SF29 MPQ \\
Social & ACSSP; \\
Depression & BDI-II; DASS-21; \\
Cancer & TMT - A; TMT - B; TMT - A \& B; \\
Life quality & SF36; Q-LES-Q-SF; \\
Post-anesthesia & QoR-40; \\
recovery & \\
Protesis & PEQ; \\
Cognitive & MoCA; FAB; \\
\hline
\end{tabular}

patients' motivation and interest to remain in the treatment. Furthermore, when using activities that involve immersive VR, it increases the patient's focus and concentration in carrying out the activities. This item is due to a feature of immersive VR in which there is an escape from reality where the sense of reality is more evident, causing the brain to be fooled and take that situation as true.

\section{Conclusion}

Considering the researched articles, there are common conditions about the problems that virtual reality can solve:

- The diversion of attention, causing procedures. mainly for the control of pain and anxiety can be minimized.

- Motivation, virtual reality has shown that it is effective and brings a new lease of life to rehabilitation treatments.

- No studies reported risks to the patient in the groups that used virtual reality tools as therapy.

- All the works presented considered virtual reality as a complementary treatment, in no article there was a substitution of a traditional treatment.

- It is common agreement that the authors show interest and are optimistic about the use of virtual reality as a therapeutic tool, but further studies are needed to prove its effectiveness.

- The number of sessions per week varies according to the treatment objective, between 1 and 7 times a week. To identify the appropriate duration and application times, it is necessary to understand the objective of the treatment, considering the planning of the rehabilitation specialist as a determinant factor.

The characteristics observed that prove the effectiveness of a clinical trial using virtual reality in rehabilitation treatments vary according to the rehabilitation objective. As factors observed regardless of the purpose of the application is the fact of attraction and motivation. Identifying the patient's profile considering the age group and what he is interested in was taken into account in all studies. It is not necessary to create your own software to work VR in a rehabilitation process, only $20.63 \%$ of the researched works used or developed their own software for rehabilitation treatments, while $79.36 \%$ of the works used software that 
had entertainment as their final purpose. Thus, it was possible to identify that, in order to be effective in the use of these applications, the intervention of the rehabilitation specialist is necessary to plan the activities according to the treatment objective and to select the activities that are suitable for this purpose. Another relevant factor is the need to use some haptic device or support so that the patient can perform the activities properly as found in the authors Lee et al. [63], Kutlu et al. [92], Calabrò et al. [100], Dimbwadyo-Terrer et al. [57], Hassett et al. [69] and France and Thomas [79].

\section{Acknowledgments}

The first author acknowledges the financial support of the National Council for the Improvement of Higher Education (CAPES).

\section{Conflicts of Interest}

We declare that we do not have any conflict of interest regarding the work.

\section{Scronyms}

GMFCS - Gross Motor Function Classification System; MACS - Manual Ability Classification System; FMA - The Fugl-Meyer Assessment; WMFT - Wolf Motor Function Test; MAS - Motor Assessment Scale; VAS - Visual Analog Scale; BAT - Behavioral Avoidance Test; FSQ - Fear of Spiders Questionnaire; SBQ - Spider Phobia Beliefs Questionnaire; mYPAS-SF - ofModified Yale Preoperative Anxiety Scale Short Form; H.P heart pulse rate; W-B faces - Wong-Baker Faces; W-DEQ - Questionnaires of Fear of Childbirth; CSS - Clinician Severity Scale; GPTS-B - Paranoid Thoughts Scale - Part B; PEQ - Prosthetic Evaluation Questionnaire; CFS - childrenś fear scale; Q-LES-Q-SF Quality of Life Enjoyment and Satisfaction Questionnaire-Short Form; DCDQ Developmental Coordination Disorder Questionnaire; MABC-2 - Movement ABC-2; FPS-R - Faces Pain Scale-Revised; PedIMMPACT - Pain Assessment in Clinical Trials; MoCA - Montreal Cognitive Assessment; HRS-A - Health Resources and Services Administration; TMT-A - Trail Making Test Part A; TMT-B - Trail Making Test Part B; TMT B-A - Trail Making Test Part A \& B; TUG - Timed Up and Go test; FRT - Functional Reach test; FAB - Frontal Assessment Battery; 10MWT - 10-m walk test; MMT - manual muscle test; SUDS - Subjective Units of Distress Scale; BBS - Berg Balance Scale; ICC induction compliance checklist; POMS - Perfil dos Estados de Humor; ATEC - Autism Treatment Evaluation Checklist; SUDs - Subjective Units of Discomfort; TMS Transcranial Magnetic Stimulation; WBS - Wong-Baker FACES; PRS - Pain Rating Scale; CFS - Child Fear Scale; FAS - Faces Anxiety Scale; CAM-S - Children's Anxiety Meter-State; FIM - Functional Independence Measure; JAAT - Joint-attention assessment task; QoR-40 - Quality of Recovery Survey; SUS - Slate-Usoh-Steed; SSQ - Simulator Sickness Questionnaire; FMS - Fast Motion sickness Scale; ATHQ - Attitudes Towards Heights Questionnaire; AES/DES - Anxiety and Danger Expectancy scales; SSQ Simulator Sickness Questionnaire; STAI - State-Trait Anxiety Inventory; MFIS Modified-Fatigue Impact Scale; ADM - amplitude de movimento ativa do joelho; SFGDS Short Form Geriatric Depression Scale; NRS - Numerical Rating Scale; CFS - Child Fear Scale; CAPS - Children Anxiety and Pain Scale; MMSE - Mini Exame do Estado Mental; PI - retroactive pain intensity; m-YPAS - Yale Preoperative Anxiety Scale; DTCs - Gait Performance, dual-task costs; TMT - Trail Making Test; SCWT - Stroop Color and Word Test; VABS - Vineland Adaptive Behavior Scales; SF36 - Short-Form Health Survey; FAI Frenchay Activity Index; ABC scale - Activities-specific Balance Confidence Scale; FBRS Frankl behaviour rating scale; PANSS - Positive and Negative Symptom Scale; K-BIT - 
Kaufman Brief Intelligence Test.

\section{References}

[1] Rehabilitation. (2020) MedlinePlus. [Online]. Available: https://medlineplus.gov/rehabilitation.html. Accessed on: Nov., 6, 2020

[2] Rehabilitation. (2020) WHO (World Health Organization). [Online]. Available: https://www.who.int/news-room/fact-sheets/detail/rehabilitation. Accessed on: Nov., 6.

[3] Cury, V. C. R. and Brandão, M. de B. (2011) Reabilitação Em Paralisia Cerebral. Medbook, Rio de Janeiro, pp.460.

[4] Bill \& Melida Gates Organizations. (2020) Clinical Trials. [Online]. Available: https://docs.gatesfoundation.org/documents/clinical_trials.pdf. Accessed on: Nov., 6.

[5] What are neurological disorders?. (2020) World Health Organization. [Online]. Available: https://www.who.int/news-room/q-a-detail/what-are-neurological-disorders. Accessed on: Nov., 6.

[6] Clinical trial (2020) World Health Organization.[Online]. Available: . Accessed on: Dec., 2.

[7] de Oliveira, Juliana M., et al. (2020) REHAB FUN: An Assistive Technology in Neurological Motor Disorders Rehabilitation of Children with Cerebral Palsy. Neural Computing and Applications, vol. 32, p. 10957-70. DOI.org (Crossref), https://doi.org/10.1007/s00521-019-04059-2.

[8] You, S. H. et al. (2005) Cortical Reorganization Induced by Virtual Reality Therapy in a Child with Hemiparetic Cerebral Palsy. Developmental Medicine and Child Neurology, vol. 47, no 9, pp. 628-635.

[9] Aran, O. T. et al. (2020) Effectiveness of the Virtual Reality on Cognitive Function of Children with Hemiplegic Cerebral Palsy: A Single-Blind Randomized Controlled Trial". International Journal of Rehabilitation Research, vol. 43, no 1, pp. 12-19.

[10] da Silva, T. D. et al. (2020) Effect of Combined Therapy of Virtual Reality and Transcranial Direct Current Stimulation in Children and Adolescents With Cerebral Palsy: A Study Protocol for a Triple-Blinded Randomized Controlled Crossover Trial. Frontiers in Neurology, vol. 11, pp. 953.

[11] Mekbib, D. B. et al., (2020) Virtual Reality Therapy for Upper Limb Rehabilitation in Patients with Stroke: A Meta-Analysis of Randomized Clinical Trials. Brain Injury, vol. 34, no 4, pp. 456-465.

[12] Vourvopoulos, A. et al., (2019) Effects of a Brain-Computer Interface With Virtual Reality (VR) Neurofeedback: A Pilot Study in Chronic Stroke Patients. Frontiers in Human Neuroscience, vol. 13, pp. 210.

[13] Miloff, A. et al. (2019) Automated Virtual Reality Exposure Therapy for Spider Phobia vs. in-Vivo One-Session Treatment: A Randomized Non-Inferiority Trial. Behaviour Research and Therapy, vol. 118, pp. 130-140.

[14] Gujjar, K. R. and Wijk, A. V. and Kumar, R. and de Jongh, A. (2019) Efficacy of Virtual Reality Exposure Therapy for the Treatment of Dental Phobia in Adults: A Randomized Controlled Trial. Journal of Anxiety Disorders, vol. 62, pp. 100-108.

[15] Emmelkamp, P. M. G., and Meyerbröker, K. and Morina, N. (2020) Virtual Reality Therapy in Social Anxiety Disorder. Current Psychiatry Reports, vol. 22, no 7, pp. 32.

[16] Maskey, M. et al., (2019) Using Virtual Reality Environments to Augment Cognitive Behavioral Therapy for Fears and Phobias in Autistic Adults. Autism in Adulthood, vol. 1, no 2, pp. 134-145.

[17] Miller, I. T. and Wiederhold, B. K. and Miller, C. S. and Wiederhold, M. D. (2020) 
Virtual Reality Air Travel Training with Children on the Autism Spectrum: A Preliminary Report. Cyberpsychology, Behavior, and Social Networking, vol. 23, no 1 , pp. 10-15.

[18] McCleery, J. P. et al. (2020) Safety and Feasibility of an Immersive Virtual Reality Intervention Program for Teaching Police Interaction Skills to Adolescents and Adults with Autism. Autism Research, vol. 13, no 8, pp. 1418-1424.

[19] Johnston, D. and Egermann, H. and Kearney, G. (2020) SoundFields: A Virtual Reality Game Designed to Address Auditory Hypersensitivity in Individuals with Autism Spectrum Disorder. Applied Sciences, vol. 10, no 9, pp. 2996.

[20] Santos, C. M. da C. and Pimenta, C. A. de M and Nobre, M. R. C. (2007) The PICO strategy for the research question construction and evidence search. Rev Latinoam Enfermagem. [Online]. Available: www.eerp.usp.br/rlae. [Online]. Available: https://edisciplinas.usp.br/pluginfile.php/4396124/mod_resource/content/1 12007\%20Estrat\%C3\%A9gia\%20PICO.pdf\#: :text=PICO\%20representa\%2 Oum\%20acr\%C3\%B4nimo\%20para,10\%2C13\%2D15. Accessed on: Nov., 6, 2020.

[21] Neurological Problem Symptoms, Causes and Effects. (2021) PsychGuides.com. [Online]. Available: https://www.psychguides.com/neurological-disorders/. Accessed on: Mar., 26.

[22] Neurological Diseases \& Disorders A-Z from NINDS. BrainFacts.org. (2021) [Online]. Available: https://www.brainfacts.org/diseases-and-disorders/neurological-disordersaz. Accessed on: Mar., 26.

[23] Neurological Diseases and Disorders. (2021) National Institute of Environmental Health Science. [Online]. Available: https://www.niehs.nih.gov/research/programs/geh/climatechange/health_i mpacts/neurological_diseases/index.cfm. Accessed on: Mar., 26.

[24] K. T. Thakur, et al, (2016) Chapter 5 Neurological Disorders. In: Mental, Neurological, and Substance Use Disorders: Disease Control Priorities, Third Edition (Volume 4). Washington (DC): The International Bank for Reconstruction and Development / The World Bank. Chapter 5. [Online]. Available: https://www.ncbi.nlm.nih.gov/pubmed/27227247.

[25] Neurological Disorders: Public Health Challenges. (2016) World Health Organization. Third Edition (Volume 4).

[26] Neurological Conditions We Treat. Cedars Sinai. (2021) [Online]. Available: https://www.cedars-sinai.org/programs/neurology-neurosurgery/conditions.html. Accessed on: Mar., 26, 2021.

[27] Movement Disorders. MedlinePlus. (2021) [Online]. Available: https://www.aans.org/Patients/Neurosurgical-Conditions-and-Treatments/MovementDisorders. Accessed on: Mar., 26, 2021.

[28] Mink, J. W. and Sanger, T. D. (2017) Swaiman's Pediatric Neurology, Movement Disorders. American Association of Neurological Surgeons. Sixth Edition.

[29] Pascual, J. M. in Rosenberg's (2020) Molecular and Genetic Basis of Neurological and Psychiatric Disease (Sixth Edition). [Online]. Available: https://www.sciencedirect.com/topics/neuroscience/movement-disorder. Accessed on: Mar., 26, 2021.

[30] R. Leonardo. (2018) PICO: Model for Clinical Questions. Evidence-Based Medicine and Practice. Brazilian Network of Research in Meta-analysis - BRAMETIS.

[31] RUSH University Medical Center Library: Evidence Based Practice (EBP): Critical Appraisal of Study Designs.(2020) RUSH I Library of Rush University Medical Center and McCormick Educational Technology Center (METC).

[32] Latta, J. N. and Oberg, D. J. (1994) A conceptual virtual reality. IEEE Computer Graphics \& Applications, v. 14, n. 1, p. 23-29.

[33] Burdea, G. and Coiffet, P. (1994) Virtual reality technology. New York, USA: John 
Wiley \& Sons.

[34] Tori, R. and Kirner, C. and Siscoutto, R. (2006) Fundamentos de realidade virtual. Org. Fundamentos e tecnologia da realidade virtual e aumentada. Belém, Pa: By Editors And Authors. pp. 2-21.

[35] Morie, J. F. (1994) Inspiring the future: merging mass communication, art, entertainment and virtual environments. Computer Graphics, v. 28, n. 2, pp. 135-138.

[36] Lima, C. M. (2001) Desenvolvimento de conteúdo para o ensino da tecnologia do plasma utilizando técnicas de multimídia e realidade virtual. Dissertação (Mestrado em Engenharia Mecânica) - Universidade Federal do Rio Grande do Norte, Natal.

[37] Rocha, F. F. et al. (2010) Otimização de nuvens de pontos densas para softwares de visualização em ambiente de realidade virtual. [Online]. Available: http://www.abcm.org.br/anais/conem/2010/PDF/CON10-1177.pdf. Accessed on: Mar., 26, 2021.

[38] Rosenbaum, P. L. et al., (2008) The Definition and Classification of Cerebral Palsy. Developmental Medicine \& Child Neurology, vol. 49, pp. 1-44. [Online]. Available: https://onlinelibrary.wiley.com/doi/epdf/10.1111/ j.1469-8749.2007.tb12610.x. Accessed on: Mar., 26, 2021.

[39] Walker, K. and Karlsson, P. and Novak, I. and Badawi, N. (2017) Cerebral palsies. The Cambridge Encyclopedia of Child Development, organizado por Brian Hopkins et al., 2o ed, Cambridge University Press, pp. 635-640.

[40] Proctor, K. (2021) Types of Cerebral Palsy - Learn More About Your Child's CP. Cerebral Palsy Guide. [Online]. Available: https://www.cerebralpalsyguide.com/cerebral-palsy/types/. Accessed on: Mar., 26.

[41] Cerebral Palsy: Symptoms, Causes, Types, and Treatments. (2018) Healthline. [Online]. Available: https://www.healthline.com/health/cerebral-palsy. Accessed on: Mar., 29, 2021.

[42] Hoon, A. and Johnston, M.V. (2002) Cerebral palsy. Diseases of the Nervous System, organizado por Arthur K. Asbury et al., 3o ed, Cambridge University Press, pp. $568-580$.

[43] Shorvon, S. et al., (2019) Cerebral Palsy. The Causes of Epilepsy, 2o ed, Cambridge University Press, pp. 794-800.

[44] Types of Cerebral Palsy - Learn More. Cerebral Palsy Group, [Online]. Available: https://cerebralpalsygroup.com/cerebral-palsy/types-of-cerebral-palsy/. Accessed on: Mar., 29, 2021.

[45] Wootla B, et al. Evidence for the role of B cells and immunoglobulins in the pathogenesis of multiple sclerosis. Neurol Res Int. 2011;2011:780712.

[46] Comabella M, et al. Immunopathogenesis of multiple sclerosis. Clin Immunol. 2012;142:2-8.

[47] Trapp BD, et al. (2008) Multiple sclerosis: an immune or neurodegenerative disorder? Ann Rev Neurosci.31:247-69.

[48] Frohman EM, et al. (2006) Multiple sclerosis: the plaque and its pathogenesis. N Engl J Med. 354:942-55.

[49] Compston A and Coles A. (2008) Multiple sclerosis. Lancet. 372:1502-17.

[50] World Health Organization. (2006) Global burden of neurological disorders: estimates and projections. In: Neurological Disorders: Public Health Challenges. Geneva, Switzerland: WHO Press.

[51] CANCHILD. Gross Motor Function Measure (GMFM). [Online]. Available: https://canchild.ca/en/resources/44-gross-motor-function-measure-gmfm. Accessed on: Apr., 29, 2021. 
[52] Franjoine, M R; Gunther, J S; Taylor, MJ. (1999) 7 THE PEDIATRIC BALANCE SCALE, Pediatric Physical Therapy: Winter 1999 - Volume 11 - Issue 4 - p 216

[53] Fernandes, M. C. C. (2019). Tradução e adaptação transcultural para uso no Brasil do teste de proficiência motora Bruininks-Oseretsky (BOT 2). 1 recurso online (191 p.). Tese (doutorado) - Universidade Estadual de Campinas, Faculdade de Ciências Médicas, Campinas, SP. [Online]. Available: http://repositorio.unicamp.br/jspui/handle/REPOSIP/336284. Accessed on: Apr., 29, 2021.

[54] CIF - Classificação Internacional da Funcionalidade, Incapacidade e Saúde. Organização Mundial da Saúde. [Online]. Available: http://www.periciamedicadf.com.br/cif2/cif_portugues.pdf. Accessed on: Apr., 29, 2021.

[55] Perry, Briana N., et al. (2018) Clinical Trial of the Virtual Integration Environment to Treat Phantom Limb Pain With Upper Extremity Amputation. Frontiers in Neurology, vol. 9, p. 770. DOI.org (Crossref), https://doi.org/10.3389/fneur.2018.00770.

[56] Amaral, Carlos, et al. (2018) A Feasibility Clinical Trial to Improve Social Attention in Autistic Spectrum Disorder (ASD) Using a Brain Computer Interface. Frontiers in Neuroscience, vol. 12, p. 477. DOI.org (Crossref), https://doi.org/10.3389/fnins.2018.00477.

[57] Dimbwadyo-Terrer, I., et al. (2016) Effectiveness of the Virtual Reality System Toyra on Upper Limb Function in People with Tetraplegia: A Pilot Randomized Clinical Trial. BioMed Research International, vol. 2016, p. 1-12. DOI.org (Crossref), https://doi.org/10.1155/2016/6397828.

[58] De Luca, Rosaria, et al. (2019) Improving Cognitive Function after Traumatic Brain Injury: A Clinical Trial on the Potential Use of the Semi-Immersive Virtual Reality. Behavioural Neurology, vol. p. 1-7. DOI.org (Crossref), https://doi.org/10.1155/2019/9268179.

[59] Gandolfi, Marialuisa, et al. (2017) Virtual Reality Telerehabilitation for Postural Instability in Parkinson's Disease: A Multicenter, Single-Blind, Randomized, Controlled Trial. BioMed Research International, vol. p. 1-11. DOI.org (Crossref), https://doi.org/10.1155/2017/7962826.

[60] Waliño-Paniagua, Carmen Nélida, et al. (2019) Effects of a Game-Based Virtual Reality Video Capture Training Program Plus Occupational Therapy on Manual Dexterity in Patients with Multiple Sclerosis: A Randomized Controlled Trial. Journal of Healthcare Engineering, vol. 2019, p. 1-7. DOI.org (Crossref), https://doi.org/10.1155/2019/9780587.

[61] Silva, J. P. L. N. et al. (2018) Effects of Conventional and Virtual Reality Cardiovascular Rehabilitation in Body Composition and Functional Capacity of Patients with Heart Diseases: Randomized Clinical Trial. International Journal of Cardiovascular Sciences. DOI.org (Crossref), https://doi.org/10.5935/2359-4802.20180071.

[62] Ribeiro, Silvia Oliveira, et al. (2017) Influence of virtual reality on postural balance and quality of life of pregnant women: controlled clinical trial randomized. Fisioterapia em Movimento, vol. 30, no suppl 1, p. 111-20. DOI.org (Crossref), https://doi.org/10.1590/1980-5918.030.s01.ao11.

[63] Lee, Suhyun, et al. (2016) Effect of Virtual Reality-Based Bilateral Upper Extremity Training on Upper Extremity Function after Stroke: A Randomized Controlled Clinical Trial: Bilateral Upper Extremity Training in Post Stroke. Occupational Therapy International, vol. 23, no 4, p. 357-68. DOI.org (Crossref), https://doi.org/10.1002/oti.1437.

[64] Yang, Y. J. Daniel, et al. (2018) Neural Mechanisms of Behavioral Change in Young Adults with High-Functioning Autism Receiving Virtual Reality Social Cognition Training: A Pilot Study: Neural Mechanisms Underlying Treatment 
Effects. Autism Research, vol. 11, no 5, p. 713-25. DOI.org (Crossref), https://doi.org/10.1002/aur.1941.

[65] Tejera, David, et al. (2020) Effects of Virtual Reality versus Exercise on Pain, Functional, Somatosensory and Psychosocial Outcomes in Patients with NonSpecific Chronic Neck Pain: A Randomized Clinical Trial. International Journal of Environmental Research and Public Health, vol. 17, no 16, p. 5950. DOI.org (Crossref), https://doi.org/10.3390/ijerph17165950.

[66] Norouzi-Gheidari, Nahid, et al. (2019) Feasibility, Safety and Efficacy of a Virtual Reality Exergame System to Supplement Upper Extremity Rehabilitation Post-Stroke: A Pilot Randomized Clinical Trial and Proof of Principle. International Journal of Environmental Research and Public Health, vol. 17, no 1, p. 113. DOI.org (Crossref), https://doi.org/10.3390/ijerph17010113.

[67] Lee, Kyeongjin. (2019) Speed-Interactive Pedaling Training Using Smartphone Virtual Reality Application for Stroke Patients: Single-Blinded, Randomized Clinical Trial. Brain Sciences, vol. 9, no 11, p. 295. DOI.org (Crossref), https://doi.org/10.3390/brainsci9110295.

[68] Dellazizzo, Laura, et al. (2020) Exploring the Benefits of Virtual Reality-Assisted Therapy Following Cognitive-Behavioral Therapy for Auditory Hallucinations in Patients with Treatment-Resistant Schizophrenia: A Proof of Concept. Journal of Clinical Medicine, vol. 9, no 10, p. 3169. DOI.org (Crossref), https://doi.org/10.3390/jcm9103169.

[69] Hassett, Leanne, et al. (2020) Digitally Enabled Aged Care and Neurological Rehabilitation to Enhance Outcomes with Activity and MObility UsiNg Technology (AMOUNT) in Australia: A Randomised Controlled Trial. PLOS Medicine, organizado por Christelle Nguyen, vol. 17, no 2, p. e1003029. DOI.org (Crossref), https://doi.org/10.1371/journal.pmed.1003029.

[70] Koo, Kyo-in, et al. (2018) Enhanced Reality Showing Long-Lasting Analgesia after Total Knee Arthroplasty: Prospective, Randomized Clinical Trial. Scientific Reports, vol. 8, no 1, p. 2343. DOI.org (Crossref), https://doi.org/10.1038/s41598-018-20260-0.

[71] Garrett, Bernard M., et al. (2020) Patients Perceptions of Virtual Reality Therapy in the Management of Chronic Cancer Pain. Heliyon, vol. 6, p. e03916. DOI.org (Crossref), https://doi.org/10.1016/j.heliyon.2020.e03916.

[72] Arnoni, Joice Luiza Bruno, et al. (2019) Effects of Virtual Reality in Body Oscillation and Motor Performance of Children with Cerebral Palsy: A Preliminary Randomized Controlled Clinical Trial. Complementary Therapies in Clinical Practice, vol. 35, p. 189-94. DOI.org (Crossref), https://doi.org/10.1016/j.ctcp.2019.02.014.

[73] Al-Nerabieah, Zuhair, et al. (2020) Effectiveness of Using Virtual Reality Eyeglasses in the Waiting Room on Preoperative Anxiety: A Randomized Controlled Trial. Perioperative Care and Operating Room Management, vol. 21, p. 100129. DOI.org (Crossref), https://doi.org/10.1016/j.pcorm.2020.100129.

[74] Ikbali Afsar, Sevgi, et al. (2018) Virtual Reality in Upper Extremity Rehabilitation of Stroke Patients: A Randomized Controlled Trial. Journal of Stroke and Cerebrovascular Diseases, vol. 27, no 12, p. 3473-78. DOI.org (Crossref), https://doi.org/10.1016/j.jstrokecerebrovasdis.2018.08.007.

[75] Pedreira da Fonseca, Erika, et al. (2017) Therapeutic Effect of Virtual Reality on Post-Stroke Patients: Randomized Clinical Trial. Journal of Stroke and Cerebrovascular Diseases, vol. 26, no 1, p. 94-100. DOI.org (Crossref), https://doi.org/10.1016/j.jstrokecerebrovasdis.2016.08.035.

[76] Meyns, Pieter, et al. (2017) Can Virtual Reality Games Improve Scores on Clinical Balance Scales in Children with Cerebral Palsy: Preliminary Results of a Randomized Controlled Clinical Trial. Gait and Posture, vol. 57, p. 234-35.

[77] Lamargue, D., et al. (2020) Effect of Cognitive Rehabilitation on Neuropsychological 
and Semiecological Testing and on Daily Cognitive Functioning in Multiple Sclerosis: The REACTIV Randomized Controlled Study. Journal of the Neurological Sciences, vol. 415, p. 116929. DOI.org (Crossref), https://doi.org/10.1016/j.jns.2020.116929.

[78] Gatica-Rojas, Valeska, et al. (2017) Effectiveness of a Nintendo Wii Balance Board Exercise Programme on Standing Balance of Children with Cerebral Palsy: A Randomised Clinical Trial Protocol. Contemporary Clinical Trials Communications, vol. 6, p. 17-21. DOI.org (Crossref), https://doi.org/10.1016/j.conctc.2017.02.008.

[79] France, Christopher R., e James S. Thomas. (2018) Virtual Immersive Gaming to Optimize Recovery (VIGOR) in Low Back Pain: A Phase II Randomized Controlled Trial. Contemporary Clinical Trials, vol. 69, p. 83-91. DOI.org (Crossref), https://doi.org/10.1016/j.cct.2018.05.001.

[80] Sheehy, Lisa, et al. (2020) Implementation of a Randomized Controlled Trial on an Inpatient Stroke Rehabilitation Unit: Lessons Learned. Contemporary Clinical Trials Communications, vol. 18, p. 100563. DOI.org (Crossref), https://doi.org/10.1016/j.conctc.2020.100563.

[81] Odin, Anaïs, et al. (2018) Modulating the Internal Model of Verticality by Virtual Reality and Body-Weight Support Walking: A Pilot Study. Annals of Physical and Rehabilitation Medicine, vol. 61, no 5, p. 292-99. DOI.org (Crossref), https://doi.org/10.1016/j.rehab.2018.07.003.

[82] Pazzaglia, C., et al. (2020) Comparison of Virtual Reality Rehabilitation and Conventional Rehabilitation in Parkinson's Disease: A Randomised Controlled Trial. Physiotherapy, vol. 106, p. 36-42. DOI.org (Crossref), https://doi.org/10.1016/j.physio.2019.12.007.

[83] Huang, Xianwei, et al. (2018) The Combined Effects of Adaptive Control and Virtual Reality on Robot-Assisted Fine Hand Motion Rehabilitation in Chronic Stroke Patients: A Case Study. Journal of Stroke and Cerebrovascular Diseases, vol. 27, no 1, p. 221-28. DOI.org (Crossref), https://doi.org/10.1016/j.jstrokecerebrovasdis.2017.08.027.

[84] Amaral, Carlos P., et al. (2017) A Novel Brain Computer Interface for Classification of Social Joint Attention in Autism and Comparison of 3 Experimental Setups: A Feasibility Study. Journal of Neuroscience Methods, vol. 290, p. 105-15. DOI.org (Crossref), https://doi.org/10.1016/j.jneumeth.2017.07.029.

[85] du Sert, Olivier Percie, et al. (2018) Virtual Reality Therapy for Refractory Auditory Verbal Hallucinations in Schizophrenia: A Pilot Clinical Trial. Schizophrenia Research, vol. 197, p. 176-81. DOI.org (Crossref), https://doi.org/10.1016/j.schres.2018.02.031.

[86] Thomas, James S., et al. (2016) Feasibility and Safety of a Virtual Reality Dodgeball Intervention for Chronic Low Back Pain: A Randomized Clinical Trial. The Journal of Pain, vol. 17, no 12, p. 1302-17. DOI.org (Crossref), https://doi.org/10.1016/j.jpain.2016.08.011.

[87] Norr, Aaron M., et al. (2018) Effects of Prolonged Exposure and Virtual Reality Exposure on Suicidal Ideation in Active Duty Soldiers: An Examination of Potential Mechanisms. Journal of Psychiatric Research, vol. 103, p. 69-74. DOI.org (Crossref), https://doi.org/10.1016/j.jpsychires.2018.05.009.

[88] Manuli, Alfredo, et al. (20200 Can Robotic Gait Rehabilitation plus Virtual Reality Affect Cognitive and Behavioural Outcomes in Patients with Chronic Stroke? A Randomized Controlled Trial Involving Three Different Protocols. Journal of Stroke and Cerebrovascular Diseases, vol. 29, no 8, p. 104994. DOI.org (Crossref), https://doi.org/10.1016/j.jstrokecerebrovasdis.2020.104994.

[89] Norr, Aaron M., et al. (2019) Relationship between Change in In-Vivo Exposure Distress and PTSD Symptoms during Exposure Therapy for Active Duty Soldiers. Journal of Psychiatric Research, vol. 116, p. 133-37. DOI.org (Crossref), https://doi.org/10.1016/j.jpsychires.2019.06.013.

[90] Kairy, Dahlia, et al. (2016) Maximizing Post-Stroke Upper Limb Rehabilitation Using 
a Novel Telerehabilitation Interactive Virtual Reality System in the Patient's Home: Study Protocol of a Randomized Clinical Trial. Contemporary Clinical Trials, vol. 47, p. 49-53. DOI.org (Crossref), https://doi.org/10.1016/j.cct.2015.12.006.

[91] Keefe, Richard S. E., et al. (2016) Validation of a Computerized Test of Functional Capacity. Schizophrenia Research, vol. 175, no 1-3, p. 90-96. DOI.org (Crossref), https://doi.org/10.1016/j.schres.2016.03.038.

[92] Kutlu, M., et al. (2016) Upper-Limb Stroke Rehabilitation Using Electrode-Array Based Functional Electrical Stimulation with Sensing and Control Innovations. Medical Engineering and Physics, vol. 38, no 4, p. 366-79. DOI.org (Crossref), .

[93] Gomes, Gisele Cristine Vieira, et al. (2018) Feasibility, Safety, Acceptability, and Functional Outcomes of Playing Nintendo Wii Fit PlusTM for Frail Older Adults: A Randomized Feasibility Clinical Trial. Maturitas, vol. 118, p. 20-28. DOI.org (Crossref), https://doi.org/10.1016/j.maturitas.2018.10.002.

[94] Ortiz-Catalan, Max, et al. (2016) Phantom Motor Execution Facilitated by Machine Learning and Augmented Reality as Treatment for Phantom Limb Pain: A Single Group, Clinical Trial in Patients with Chronic Intractable Phantom Limb Pain. The Lancet, vol. 388, no 10062, p. 2885-94. DOI.org (Crossref), https://doi.org/10.1016/S0140-6736(16)31598-7.

[95] Patrício, Naiane Araújo, et al. (2020) Effectiveness of Virtual Reality Games for Falls, Postural Oscillations, Pain and Quality of Life of Individual HAM/TSP: A Randomized, Controlled, Clinical Trial. Journal of NeuroVirology, vol. 26, no 5, p. 676-86. DOI.org (Crossref), https://doi.org/10.1007/s13365-020-00880-x.

[96] Avcil, Eren, et al. (2021) Upper Extremity Rehabilitation Using Video Games in Cerebral Palsy: A Randomized Clinical Trial. Acta Neurologica Belgica, vol. 121, no 4, p. 1053-60. DOI.org (Crossref), https://doi.org/10.1007/s13760-020-01400-8.

[97] Bourque, McKenzie O., et al. (2019) Combining Physical Therapy and Cognitive Behavioral Therapy Techniques to Improve Balance Confidence and Community Participation in People with Unilateral Transtibial Amputation Who Use Lower Limb Prostheses: A Study Protocol for a Randomized Sham-Control Clinical Trial. Trials, vol. 20, no 1, p. 812. DOI.org (Crossref), https://doi.org/10.1186/s13063-019-3929-8.

[98] Cavalcante Neto, Jorge Lopes, et al. (2019) Motor Intervention with and without Nintendo ${ }^{\circledR}$ Wii for Children with Developmental Coordination Disorder: Protocol for a Randomized Clinical Trial. Trials, vol. 20, no 1, p. 794. DOI.org (Crossref), https://doi.org/10.1186/s13063-019-3930-2.

[99] Peultier-Celli, Laetitia, et al. (2019) Comparison of High-Frequency Intensive Balneotherapy with Low-Frequency Balneotherapy Combined with Land-Based Exercise on Postural Control in Symptomatic Knee Osteoarthritis: A Randomized Clinical Trial. International Journal of Biometeorology, vol. 63, no 9, p. 1151-59. DOI.org (Crossref), https://doi.org/10.1007/s00484-019-01727-9.

[100] Calabrò, Rocco Salvatore, et al. (2017) The Role of Virtual Reality in Improving Motor Performance as Revealed by EEG: A Randomized Clinical Trial. Journal of NeuroEngineering and Rehabilitation, vol. 14, no 1, p. 53. DOI.org (Crossref), https://doi.org/10.1186/s12984-017-0268-4.

[101] Montero-Alía, Pilar, et al. (2016) Study Protocol of a Randomized Clinical Trial Evaluating the Effectiveness of a Primary Care Intervention Using the NintendoTM Wii Console to Improve Balance and Decrease Falls in the Elderly. BMC Geriatrics, vol. 16, no 1, p. 8. DOI.org (Crossref), https://doi.org/10.1186/s12877-015-0178-x.

[102] Chan, Evelyn, et al. (2019) Virtual Reality for Pediatric Needle Procedural Pain: Two Randomized Clinical Trials. The Journal of Pediatrics, vol. 209, p. 160-167.e4. DOI.org (Crossref), https://doi.org/10.1016/j.jpeds.2019.02.034.

[103] Amiri, Paria, et al. (2019) The Effect of Distraction Techniques on Pain and Stress during Labor: A Randomized Controlled Clinical Trial. BMC Pregnancy and 
Childbirth, vol. 19, no 1, p. 534. DOI.org (Crossref), https://doi.org/10.1186/s12884019-2683-y.

[104] Amin, Ashfaq M., et al. (2017) Cardboard Mobile Virtual Reality as an Approach for Pain Distraction in Clinical Settings: Comparison, Exploration and Evaluation with Oculus Rift. Proceedings of the 2017 CHI Conference Extended Abstracts on Human Factors in Computing Systems, ACM, p. 2345-51. DOI.org (Crossref), https://doi.org/10.1145/3027063.3053234.

[105] Perin, Alessandro, et al. "Informed Consent through 3D Virtual Reality: A Randomized Clinical Trial”. Acta Neurochirurgica, vol. 163, no 2, fevereiro de 2021, p. 301-08. DOI.org (Crossref), https://doi.org/10.1007/s00701-020-04303-y.

[106] Dehghan, Fateme, et al. (2019) The Effect of Virtual Reality Technology on Preoperative Anxiety in Children: A Solomon Four-Group Randomized Clinical Trial. Perioperative Medicine, vol. 8, no 1, p. 5. DOI.org (Crossref), https://doi.org/10.1186/s13741-019-0116-0.

[107] Ghadimi, S., et al. (2018) Effect of Visual Distraction on Children's Anxiety during Dental Treatment: A Crossover Randomized Clinical Trial. European Archives of Paediatric Dentistry, vol. 19, no 4, p. 239-44. DOI.org (Crossref), https://doi.org/10.1007/s40368-018-0352-x.

[108] Ryu, J-H, et al. (2017) Randomized Clinical Trial of Immersive Virtual Reality Tour of the Operating Theatre in Children before Anaesthesia. British Journal of Surgery, vol. 104, no 12, p. 1628-33. DOI.org (Crossref), https://doi.org/10.1002/bjs.10684.

[109] Liu, Wang, et al. (2020) Memory Retrieval-Extinction Combined With Virtual Reality Reducing Drug Craving for Methamphetamine: Study Protocol for a Randomized Controlled Trial. Frontiers in Psychiatry, vol. 11, p. 322. DOI.org (Crossref), https://doi.org/10.3389/fpsyt.2020.00322.

[110] Ryu, Jung-Hee, Jin-Woo Park, Francis Nahm, et al. (2018) The Effect of Gamification through a Virtual Reality on Preoperative Anxiety in Pediatric Patients Undergoing General Anesthesia: A Prospective, Randomized, and Controlled Trial. Journal of Clinical Medicine, vol. 7, no 9, p. 284. DOI.org (Crossref), https://doi.org/10.3390/jcm7090284.

[111] Pericot-Valverde, Irene, et al. (2019) A Randomized Clinical Trial of Cue Exposure Treatment through Virtual Reality for Smoking Cessation. Journal of Substance Abuse Treatment, vol. 96, p. 26-32. DOI.org (Crossref), https://doi.org/10.1016/j.jsat.2018.10.003.

[112] Park, Jin-Woo, et al. (2019) The Effect of Mirroring Display of Virtual Reality Tour of the Operating Theatre on Preoperative Anxiety: A Randomized Controlled Trial. IEEE Journal of Biomedical and Health Informatics, vol. 23, no 6, p. 2655-60. DOI.org (Crossref), https://doi.org/10.1109/JBHI.2019.2892485.

[113] Deutsch, Judith, et al. (2017) Participation outcomes differed between video gamebased balance training and standard of care training: Pilot clinical trial. 2017 International Conference on Virtual Rehabilitation (ICVR), IEEE, p. 1-7. DOI.org (Crossref), https://doi.org/10.1109/ICVR.2017.8007544.

[114] Hamzeheinejad, Negin, et al.(2018) Immersive Robot-Assisted Virtual Reality Therapy for Neurologically-Caused Gait Impairments. 2018 IEEE Conference on Virtual Reality and 3D User Interfaces (VR), IEEE, 2018, p. 565-66. DOI.org (Crossref), https://doi.org/10.1109/VR.2018.8446125.

[115] Fluet, Gerard, et al. (2017) Early versus delayed VR-based hand training in persons with acute stroke. 2017 International Conference on Virtual Rehabilitation (ICVR), IEEE, p. 1-7. DOI.org (Crossref), https://doi.org/10.1109/ICVR.2017.8007490.

[116] Peng, Liang, et al. (2017) Robot assisted upper limb rehabilitation training and clinical evaluation: Results of a pilot study. 2017 IEEE International Conference on Robotics and Biomimetics (ROBIO), IEEE, p. 2740-45. DOI.org (Crossref), 
https://doi.org/10.1109/ROBIO.2017.8324530.

[117] Amritha, N., et al. (2016) Design and development of balance training platform and games for people with balance impairments. 2016 International Conference on Advances in Computing, Communications and Informatics (ICACCI), IEEE, p. 960-66. DOI.org (Crossref), https://doi.org/10.1109/ICACCI.2016.7732169.

[118] Bortone, Ilaria, et al. (2018) Wearable Haptics and Immersive Virtual Reality Rehabilitation Training in Children With Neuromotor Impairments. IEEE Transactions on Neural Systems and Rehabilitation Engineering, vol. 26, no 7, p. 1469-78. DOI.org (Crossref), https://doi.org/10.1109/TNSRE.2018.2846814.

[119] Maier, Martina, et al. (2017) Conjunctive rehabilitation of multiple cognitive domains for chronic stroke patients in virtual reality. 2017 International Conference on Rehabilitation Robotics (ICORR), IEEE, p. 947-52. DOI.org (Crossref), https://doi.org/10.1109/ICORR.2017.8009371.

[120] Batson, Josiah P., et al. (2020) Haptic Coupling in Dyads Improves Motor Learning in a Simple Force Field. 2020 42nd Annual International Conference of the IEEE Engineering in Medicine and Biology Society (EMBC), IEEE, p. 4795-98. DOI.org (Crossref), .

[121] Hsieh, K. L., et al. (2020) A Multi-Modal Virtual Reality Treadmill Intervention for Enhancing Mobility and Cognitive Function in People with Multiple Sclerosis: Protocol for a Randomized Controlled Trial. Contemporary Clinical Trials, vol. 97, p. 106122. DOI.org (Crossref), https://doi.org/10.1016/j.cct.2020.106122.

[122] Koç Özkan, Tuba, e Filiz Polat. (2020) The Effect of Virtual Reality and Kaleidoscope on Pain and Anxiety Levels During Venipuncture in Children. Journal of PeriAnesthesia Nursing, vol. 35, no 2, p. 206-11. DOI.org (Crossref), https://doi.org/10.1016/j.jopan.2019.08.010.

[123] Lee, Soon Young, e Jiyeon Kang. (2020) Effect of Virtual Reality Meditation on Sleep Quality of Intensive Care Unit Patients: A Randomised Controlled Trial. Intensive and Critical Care Nursing, vol. 59, p. 102849. DOI.org (Crossref), https://doi.org/10.1016/j.iccn.2020.102849.

[124] Brown, Poppy, et al. (2020) Power Posing for Paranoia: A Double-Blind Randomised Controlled Experimental Test Using Virtual Reality. Behaviour Research and Therapy, vol. 132, p. 103691. DOI.org (Crossref), https://doi.org/10.1016/j.brat.2020.103691.

[125] Barsasella, Diana, et al. (2021) Effects of Virtual Reality Sessions on the Quality of Life, Happiness, and Functional Fitness among the Older People: A Randomized Controlled Trial from Taiwan. Computer Methods and Programs in Biomedicine, vol. 200, p. 105892. DOI.org (Crossref), https://doi.org/10.1016/j.cmpb.2020.105892.

[126] Gerçeker, Gülçin Özalp, et al. (2021) The Effect of Virtual Reality on Pain, Fear, and Anxiety during Access of a Port with Huber Needle in Pediatric Hematology-Oncology Patients: Randomized Controlled Trial. European Journal of Oncology Nursing, vol. 50, p. 101886. DOI.org (Crossref), https://doi.org/10.1016/j.ejon.2020.101886.

[127] Yeo, N. L., et al. (2020) What Is the Best Way of Delivering Virtual Nature for Improving Mood? An Experimental Comparison of High Definition TV, $360^{\circ}$ Video, and Computer Generated Virtual Reality. Journal of Environmental Psychology, vol. 72, p. 101500. DOI.org (Crossref), https://doi.org/10.1016/j.jenvp.2020.101500.

[128] Molhemi, Farshad, et al. (2021) Effects of Virtual Reality vs Conventional Balance Training on Balance and Falls in People With Multiple Sclerosis: A Randomized Controlled Trial. Archives of Physical Medicine and Rehabilitation, vol. 102, no 2, p. 290-99. DOI.org (Crossref), https://doi.org/10.1016/j.apmr.2020.09.395.

[129] Thielbar, Kelly O., et al. (2020) Home-Based Upper Extremity Stroke Therapy Using a Multiuser Virtual Reality Environment: A Randomized Trial. Archives of Physical Medicine and Rehabilitation, vol. 101, no 2, p. 196-203. DOI.org (Crossref), https://doi.org/10.1016/j.apmr.2019.10.182. 
[130] Tennant, Michelle, et al. (2020) Exploring the Use of Immersive Virtual Reality to Enhance Psychological Well-Being in Pediatric Oncology: A Pilot Randomized Controlled Trial. European Journal of Oncology Nursing, vol. 48, p. 101804. DOI.org (Crossref), https://doi.org/10.1016/j.ejon.2020.101804.

[131] Melcer, Yaakov, et al. (2021) Analgesic Efficacy of Virtual Reality for Acute Pain in Amniocentesis: A Randomized Controlled Trial. European Journal of Obstetrics and Gynecology and Reproductive Biology, vol. 261, p. 134-38. DOI.org (Crossref), .

[132] Kakoschke, Naomi, et al. (2021) Brain Training with the Body in Mind: Towards Gamified Approach-Avoidance Training Using Virtual Reality. International Journal of Human-Computer Studies, vol. 151, p. 102626. DOI.org (Crossref), https://doi.org/10.1016/j.ijhcs.2021.102626.

[133] Erdogan, Birgül, e Aynur Aytekin Ozdemir. (2021) The Effect of Three Different Methods on Venipuncture Pain and Anxiety in Children: Distraction Cards, Virtual Reality, and Buzzy ${ }^{\circledR}$ (Randomized Controlled Trial). Journal of Pediatric Nursing, vol. 58, p. e54-62. DOI.org (Crossref), https://doi.org/10.1016/j.pedn.2021.01.001.

[134] Machulska, Alla, et al. (2021) Approach Bias Retraining through Virtual Reality in Smokers Willing to Quit Smoking: A Randomized-Controlled Study. Behaviour Research and Therapy, vol. 141, p. 103858. DOI.org (Crossref), https://doi.org/10.1016/j.brat.2021.103858.

[135] Buyuk, Esra Tural, et al. (2021) The Effect of Virtual Reality on Children's Anxiety, Fear, and Pain Levels before Circumcision. Journal of Pediatric Urology, p. S1477513121002151. DOI.org (Crossref), https://doi.org/10.1016/j.jpurol.2021.04.008.

[136] Sulfikar Ali, A., et al. (2021) Effectiveness of an Intensive, Functional, Gamified Rehabilitation Program in Improving Upper Limb Motor Function in People with Stroke: A Protocol of the EnteRtain Randomized Clinical Trial. Contemporary Clinical Trials, vol. 105, p. 106381. DOI.org (Crossref), https://doi.org/10.1016/j.cct.2021.106381.

[137] Johnson, Liam, et al. "An Innovative STRoke Interactive Virtual ThErapy (STRIVE) Online Platform for Community-Dwelling Stroke Survivors: A Randomized Controlled Trial". Archives of Physical Medicine and Rehabilitation, vol. 101, no 7, julho de 2020, p. 1131-37. DOI.org (Crossref), https://doi.org/10.1016/j.apmr.2020.03.011.

[138] Marques-Sule, Elena, et al. "Effectiveness of Nintendo Wii and Physical Therapy in Functionality, Balance, and Daily Activities in Chronic Stroke Patients". Journal of the American Medical Directors Association, vol. 22, no 5, maio de 2021, p. 1073-80. DOI.org (Crossref), https://doi.org/10.1016/j.jamda.2021.01.076.

[139] Lima Rebêlo, Felipe, et al. (2021) Immersive Virtual Reality Is Effective in the Rehabilitation of Older Adults with Balance Disorders: A Randomized Clinical Trial. Experimental Gerontology, vol. 149, p. 111308. DOI.org (Crossref), https://doi.org/10.1016/j.exger.2021.111308.

[140] Kim, Hyewon, et al. (2021) Clinical Predictors of Cybersickness in Virtual Reality (VR) among Highly Stressed People. Scientific Reports, vol. 11, no 1, p. 12139. DOI.org (Crossref), https://doi.org/10.1038/s41598-021-91573-w.

[141] Bentz, Dorothée, et al. (2021) Effectiveness of a Stand-Alone, SmartphoneBased Virtual Reality Exposure App to Reduce Fear of Heights in Real-Life: A Randomized Trial. Npj Digital Medicine, vol. 4, no 1, p. 16. DOI.org (Crossref), https://doi.org/10.1038/s41746-021-00387-7.

[142] Dellazizzo, Laura, et al. (2021) One-Year Randomized Trial Comparing Virtual Reality-Assisted Therapy to Cognitive-Behavioral Therapy for Patients with Treatment-Resistant Schizophrenia. Npj Schizophrenia, vol. 7, no 1, p. 9. DOI.org (Crossref), https://doi.org/10.1038/s41537-021-00139-2.

[143] Kim, Hayeon, et al. (2020) Neuroplastic Effects of End-Effector Robotic Gait 
Training for Hemiparetic Stroke: A Randomised Controlled Trial. Scientific Reports, vol. 10, no 1, p. 12461. DOI.org (Crossref), https://doi.org/10.1038/s41598-020-693673.

[144] Zeigelboim, Bianca Simone, et al. (2021) Balance Rehabilitation with a Virtual Reality Protocol for Patients with Hereditary Spastic Paraplegia: Protocol for a Clinical Trial. PLOS ONE, organizado por Walid Kamal Abdelbasset, vol. 16, no 4, p. e0249095. DOI.org (Crossref), https://doi.org/10.1371/journal.pone.0249095.

[145] Schuster-Amft, Corina, et al. (2018) Effect of a Four-Week Virtual RealityBased Training versus Conventional Therapy on Upper Limb Motor Function after Stroke: A Multicenter Parallel Group Randomized Trial. PLOS ONE, organizado por Jacobus P. van Wouwe, vol. 13, no 10, p. e0204455. DOI.org (Crossref), https://doi.org/10.1371/journal.pone.0204455.

[146] Huang, Mark Y., et al. (2020) Effects of Immersive Virtual Reality Therapy on Intravenous Patient-Controlled Sedation during Orthopaedic Surgery under Regional Anesthesia: A Randomized Controlled Trial. PLOS ONE, organizado por Andre Scherag, vol. 15, no 2, p. e0229320. DOI.org (Crossref), https://doi.org/10.1371/journal.pone.0229320.

[147] Spiegel, Brennan, et al. (2019) Virtual Reality for Management of Pain in Hospitalized Patients: A Randomized Comparative Effectiveness Trial. PLOS ONE, organizado por Vineet Gupta, vol. 14, p. e0219115. DOI.org (Crossref), https://doi.org/10.1371/journal.pone.0219115.

[148] Botella, Cristina, et al. (2016) In Vivo versus Augmented Reality Exposure in the Treatment of Small Animal Phobia: A Randomized Controlled Trial. PLOS ONE, organizado por Ingmar H.A. Franken, vol. 11, no 2, p. e0148237. DOI.org (Crossref), https://doi.org/10.1371/journal.pone.0148237.

[149] Ramos, Alexander A., et al. (2019) Simulated Prism Exposure in Immersed Virtual Reality Produces Larger Prismatic After-Effects than Standard Prism Exposure in Healthy Subjects. PLOS ONE, organizado por Markus Lappe, vol. 14, no 5, p. e0217074. DOI.org (Crossref), https://doi.org/10.1371/journal.pone.0217074.

[150] Marshall, Jane, Tracey Booth, et al. (2016) Evaluating the Benefits of Aphasia Intervention Delivered in Virtual Reality: Results of a Quasi-Randomised Study. PLOS ONE, organizado por Peter Howell, vol. 11, no 8, p. e0160381. DOI.org (Crossref), https://doi.org/10.1371/journal.pone.0160381.

[151] Hsieh, Ru-Lan, et al. (2016) The Impact of Short-Term Video Games on Performance among Children with Developmental Delays: A Randomized Controlled Trial. PLOS ONE, organizado por Andrea Martinuzzi, vol. 11, no 3, p. e0149714. DOI.org (Crossref), https://doi.org/10.1371/journal.pone.0149714.

[152] Sielużycki, Cezary, et al. (2019) Can Kinect Aid Motor Learning in Sportsmen? A Study for Three Standing Techniques in Judo. PLOS ONE, organizado por Juliane Müller, vol. 14, no 2, p. e0210260. DOI.org (Crossref), https://doi.org/10.1371/journal.pone.0210260.

[153] Ramnath, Udhir, et al. (2021) Efficacy of Interactive Video Gaming in Older Adults with Memory Complaints: A Cluster-Randomized Exercise Intervention. PLOS ONE, organizado por Yuka Kotozaki, vol. 16, no 5, p. e0252016. DOI.org (Crossref), https://doi.org/10.1371/journal.pone.0252016.

[154] Marshall, Jane, Niamh Devane, et al. (2020) A Randomised Trial of Social Support Group Intervention for People with Aphasia: A Novel Application of Virtual Reality. PLOS ONE, organizado por Andrea Martinuzzi, vol. 15, no 9, p. e0239715. DOI.org (Crossref), https://doi.org/10.1371/journal.pone.0239715.

[155] Radder, Bob, et al. (2019) Home Rehabilitation Supported by a Wearable SoftRobotic Device for Improving Hand Function in Older Adults: A Pilot Randomized Controlled Trial. PLOS ONE, organizado por Yoshihiro Fukumoto, vol. 14, no 8, p. 
e0220544. DOI.org (Crossref), https://doi.org/10.1371/journal.pone.0220544.

[156] de la Barrera, Usue, et al. (2021) EmoTIC: Impact of a Game-Based Social-Emotional Programme on Adolescents. PLOS ONE, organizado por Eduardo Fonseca-Pedrero, vol. 16, no 4, p. e0250384. DOI.org (Crossref), https://doi.org/10.1371/journal.pone.0250384.

[157] Ryu, Jung-Hee, Jin-Woo Park, Sang Il Choi, et al. (2021) Virtual Reality vs. Tablet Video as an Experiential Education Platform for Pediatric Patients Undergoing Chest Radiography: A Randomized Clinical Trial. Journal of Clinical Medicine, vol. 10, no 11, p. 2486. DOI.org (Crossref), https://doi.org/10.3390/jcm10112486.

[158] Lee, Kyeongjin. (2020) Virtual Reality Gait Training to Promote Balance and Gait Among Older People: A Randomized Clinical Trial. Geriatrics, vol. 6, no 1, p. 1. DOI.org (Crossref), https://doi.org/10.3390/geriatrics6010001.

[159] García-Bravo, Sara, et al. (2020) Effects of Virtual Reality on Cardiac Rehabilitation Programs for Ischemic Heart Disease: A Randomized Pilot Clinical Trial. International Journal of Environmental Research and Public Health, vol. 17, no 22, p. 8472. DOI.org (Crossref), https://doi.org/10.3390/ijerph17228472.

[160] Quero, Soledad, et al. (2019) Can Between-Session Homework Be Delivered Digitally? A Pilot Randomized Clinical Trial of CBT for Adjustment Disorders. International Journal of Environmental Research and Public Health, vol. 16, no 20, p. 3842. DOI.org (Crossref), https://doi.org/10.3390/ijerph16203842.

[161] Mugueta-Aguinaga, Iranzu, e Begonya Garcia-Zapirain. (2019) Frailty Level Monitoring and Analysis after a Pilot Six-Week Randomized Controlled Clinical Trial Using the FRED Exergame Including Biofeedback Supervision in an Elderly Day Care Centre. International Journal of Environmental Research and Public Health, vol. 16, no 5, p. 729. DOI.org (Crossref), https://doi.org/10.3390/ijerph16050729.

[162] Wall, Kathryn, et al. (2018) The Enhanced Interactive Physical and Cognitive Exercise System (IPACESTM v2.0): Pilot Clinical Trial of an In-Home IPad-Based NeuroExergame for Mild Cognitive Impairment (MCI). Journal of Clinical Medicine, vol. 7, no 9, p. 249. DOI.org (Crossref), https://doi.org/10.3390/jcm7090249.

[163] —. (2017) FRED: Exergame to Prevent Dependence and Functional Deterioration Associated with Ageing. A Pilot Three-Week Randomized Controlled Clinical Trial. International Journal of Environmental Research and Public Health, vol. 14, no 12, p. 1439. DOI.org (Crossref), https://doi.org/10.3390/ijerph14121439.

[164] Le May, Sylvie, et al. (2021) Immersive Virtual Reality vs. Nonimmersive Distraction for Pain Management of Children during Bone Pins and Sutures Removal: A Randomized Clinical Trial Protocol. Journal of Advanced Nursing, vol. 77, no 1, p. 439-47. DOI.org (Crossref), .

[165] Shimizu, Nobuko, et al. (2017) An Interactive Sports Video Game as an Intervention for Rehabilitation of Community-Living Patients with Schizophrenia: A Controlled, Single-Blind, Crossover Study. PLOS ONE, organizado por Berthold Langguth, vol. 12, no 11, p. e0187480. DOI.org (Crossref), https://doi.org/10.1371/journal.pone.0187480.

[166] Fonseca, Erika Pedreira da, et al. (2021) Therapeutic effects of virtual reality video gaming on functional mobility, balance, and gait speed in individuals with tropical spastic paraparesis: A randomized crossover clinical trial. Revista da Sociedade Brasileira de Medicina Tropical, vol. 54, p. e06232020. DOI.org (Crossref), https://doi.org/10.1590/0037-8682-0623-2020.

[167] Volpi, Simiane Salete, et al. (2021) Using a Mobile Health App to Improve Patients' Adherence to Hypertension Treatment: A Non-Randomized Clinical Trial. PeerJ, vol. 9, p. e11491. DOI.org (Crossref), https://doi.org/10.7717/peerj.11491.

[168] Nasseri, Navina N., et al. (2020) Feasibility of a Smartphone App to Enhance Physical Activity in Progressive MS: A Pilot Randomized Controlled Pilot Trial over Three Months. PeerJ, vol. 8, p. e9303. DOI.org (Crossref), https://doi.org/10.7717/peerj.9303. 
[169] Collado-Mateo, Daniel, et al. (2017) Exergames for Women with Fibromyalgia: A Randomised Controlled Trial to Evaluate the Effects on Mobility Skills, Balance and Fear of Falling. PeerJ, vol. 5, p. e3211. DOI.org (Crossref), https://doi.org/10.7717/peerj.3211.

[170] Oliveira, Luciana Mendes, et al. (2021) 2D Virtual Reality-Based Exercise Improves Spatial Navigation in Institutionalized Non-robust Older Persons: A Preliminary Data Report of a Single-Blind, Randomized, and Controlled Study. Frontiers in Neurology, vol. 11, p. 609988. DOI.org (Crossref), https://doi.org/10.3389/fneur.2020.609988.

[171] Maroño Souto, Yolanda, et al. (2018) Randomized Clinical Trial with e-MotionalTraining ${ }^{\circledR} \quad 1.0$ for Social Cognition Rehabilitation in Schizophrenia. Frontiers in Psychiatry, vol. 9, p. 40. DOI.org (Crossref), https://doi.org/10.3389/fpsyt.2018.00040.

[172] Liao, Ying-Yi, et al. (2019) Effects of Virtual Reality-Based Physical and Cognitive Training on Executive Function and Dual-Task Gait Performance in Older Adults With Mild Cognitive Impairment: A Randomized Control Trial. Frontiers in Aging Neuroscience, vol. 11, p. 162. DOI.org (Crossref), https://doi.org/10.3389/fnagi.2019.00162. 